\title{
Exploring God Concepts of Christians, Muslims, and New Age Participants.
}

\author{
A thesis submitted to \\ the Faculty of Graduate Studies and Research \\ in Partial Fulfillment of the requirements for the degree \\ Master of Arts
}

by

Shelley Carolyn Taylor

Department of Psychology

Carleton University

November 2009

(C2009 Shelley C Taylor 


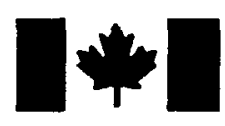

Library and Archives

Canada

Published Heritage
Branch

395 Wellington Street

Ottawa ON K1A 0N4

Canada
Bibliothèque et

Archives Canada

Direction du

Patrimoine de l'édition

395 , rue Wellington

Ottawa ON K1A ON4

Canada
Your file Votre référence
ISBN: $978-0-494-64445-4$
Our file Notre référence
ISBN: $978-0-494-64445-4$
NOTICE:

The author has granted a nonexclusive license allowing Library and Archives Canada to reproduce, publish, archive, preserve, conserve, communicate to the public by telecommunication or on the Internet, loan, distribute and sell theses worldwide, for commercial or noncommercial purposes, in microform, paper, electronic and/or any other formats.

The author retains copyright ownership and moral rights in this thesis. Neither the thesis nor substantial extracts from it may be printed or otherwise reproduced without the author's permission.
AVIS:

L'auteur a accordé une licence non exclusive permettant à la Bibliothèque et Archives Canada de reproduire, publier, archiver, sauvegarder, conserver, transmettre au public par télécommunication ou par l'Internet, prêter, distribuer et vendre des thèses partout dans le monde, à des fins commerciales ou autres, sur support microforme, papier, électronique et/ou autres formats.

L'auteur conserve la propriété du droit d'auteur et des droits moraux qui protège cette thèse. $\mathrm{Ni}$ la thèse ni des extraits substantiels de celle-ci ne doivent être imprimés ou autrement reproduits sans son autorisation.
In compliance with the Canadian Privacy Act some supporting forms may have been removed from this thesis.

While these forms may be included in the document page count, their removal does not represent any loss of content from the thesis.
Conformément à la loi canadienne sur la protection de la vie privée, quelques formulaires secondaires ont èté enlevés de cette thèse.

Bien que ces formulaires aient inclus dans la pagination, il n'y aura aucun contenu manquant. 


\begin{abstract}
It is postulated that individuals differ in how they perceive God, and these differences are associated with understanding of oneself and the social world. 635 individuals of faith (Catholic, Protestant, Muslim, and New Age/spiritual) were recruited from the Carleton student community and religious websites to complete a survey assessing conceptions of God, loci of control, assumptive worlds, coping styles and religious identity. Factor analyses of God concepts suggest four general dimensions: (1) loving-kind, (2) sternpunishing, (3) remote-quiet, and (4) unchanging-universal. Within faith group correlations indicate that for all groups, perceiving God as loving-kind is significantly and positively related to perceiving God as a locus of control, a tendency to adopt a collaborative (or deferring) religious coping style, and a tendency to identify with one's religious group. Future research is needed to assess the extent to which these God concepts remain stable over time.
\end{abstract}




\section{Acknowledgements}

Robert Frost once wrote, "Two roads diverged in a wood, and I - I took the one less traveled by, and that has made all the difference." Though my academic "road" has been taxing, it has been made rewarding by the people who traveled along with me. I would like to thank those who encouraged me to continue on this road, and who helped me grow as a student and as a person.

My most constant companion on this journey has been my academic advisor Chris Davis. To say that I am grateful for his superb guidance and extreme patience seems to be a pale platitude. As arduous as this journey has been for me, the knowledge with which Chris supported me and his excitement in regards to my research helped sustain me. Thank you Chris for all you have taught me, it will not be forgotten.

As this journey was only made possible by the support of my parents, Mel and Gladys Taylor, who without them, I would not have had the faith in myself to see it through. Thank you for putting up with my moments of doubt and for your firm belief that I was on the right "path". I love and cherish you both.

I would also like to thank four friends who like me, were on their own journeys, and for a time we shared the same road. To Erin-Michelle Clarke, Patricia Fonteine, Deanna Whelan, and Geoff Wilton, thank you for your help and support. In addition, a special thanks to my lifelong and best friend Jacqueline Wisniewski Trice. You have shared many journeys with me, and many more to come. Thank you all! 


\section{Table on Contents}

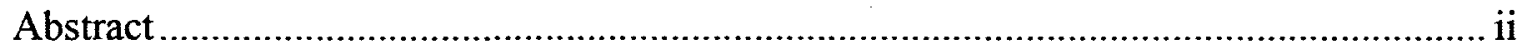

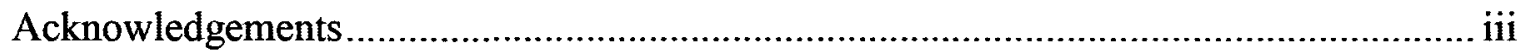

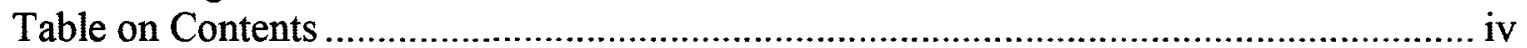

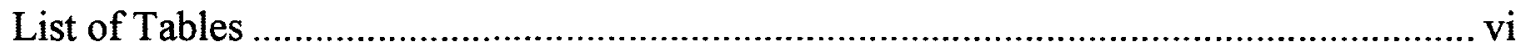

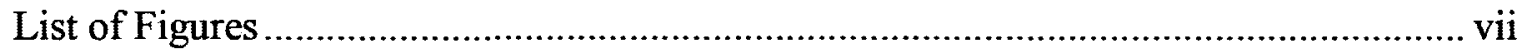

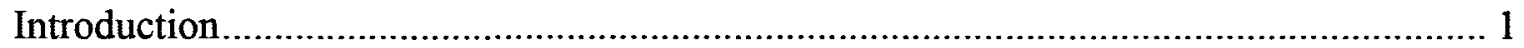

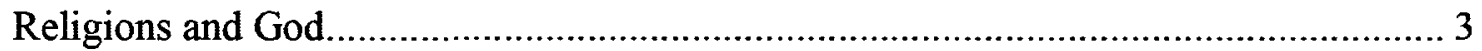

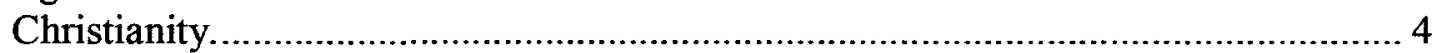

Islam

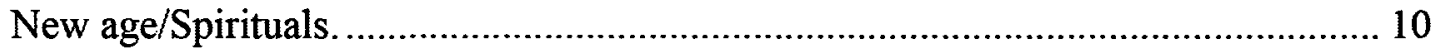

Conceptualizations of God in General ................................................................. 11

Individual conceptualizations of God ................................................................. 12

Correlates of God Concepts ................................................................................ 14

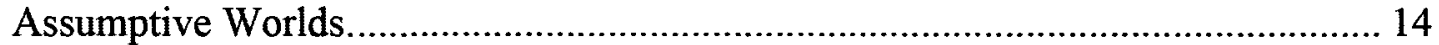

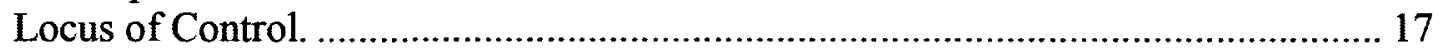

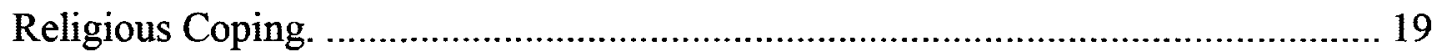

Liberal and Fundamental Religious Orientations. .................................................. 21

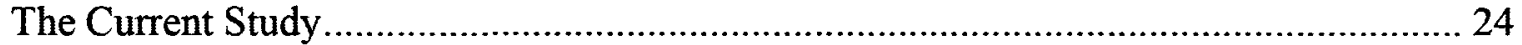

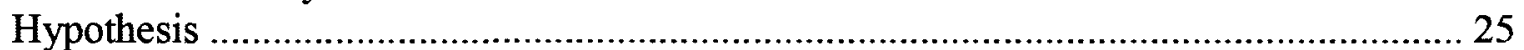

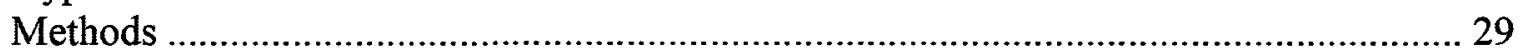

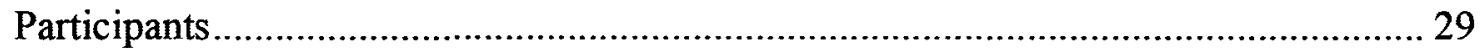

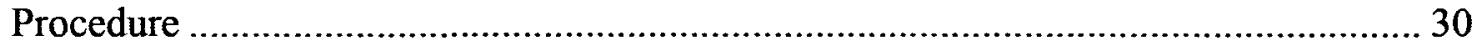

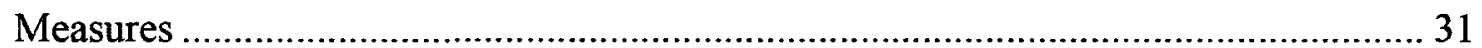

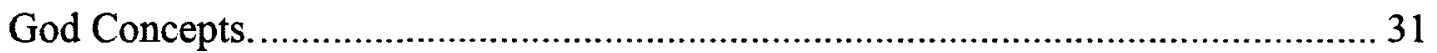

Background Questionnaire........................................................................... 38

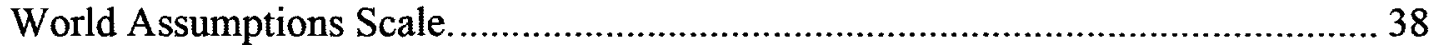

Multidimensional Locus of Control Scales: God Control Revision. ....................... 39

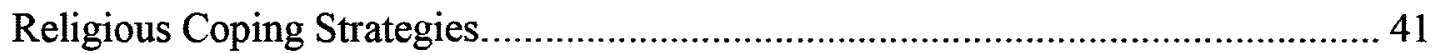

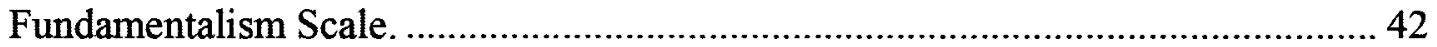

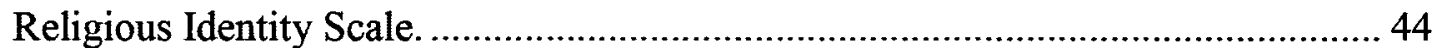

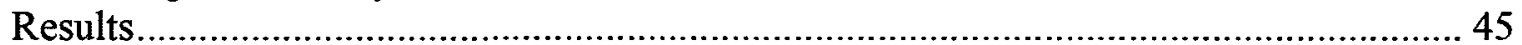

God Concept Dimensions ................................................................................. 45

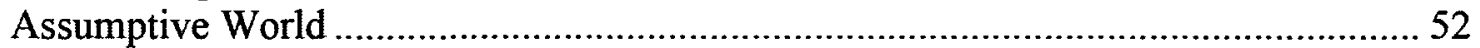

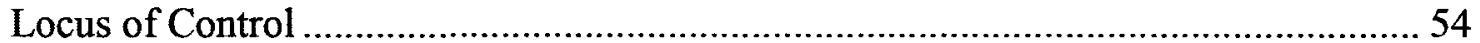

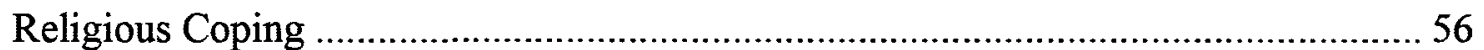

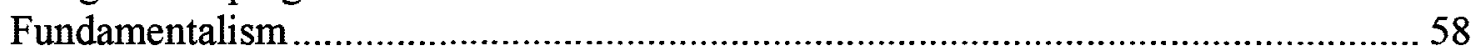

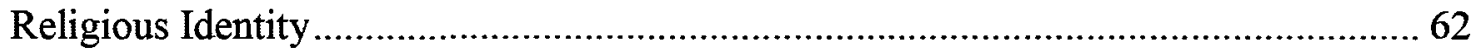

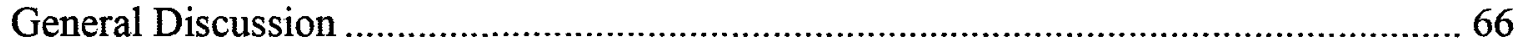




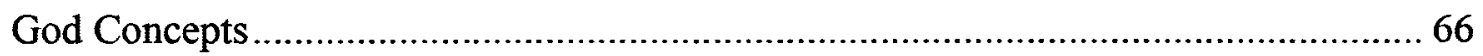

God Concepts and the Assumptive World........................................................... 70

God Concepts and Loci of Control ......................................................................... 71

God Concepts and Religious Coping .................................................................. 72

God Concepts and Fundamentalism ………............................................................ 73

God Concepts and Religious Identity ................................................................ 74

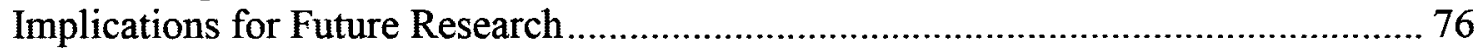

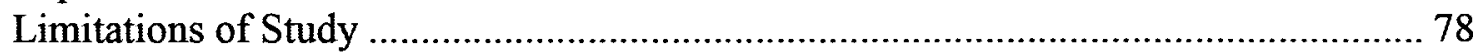

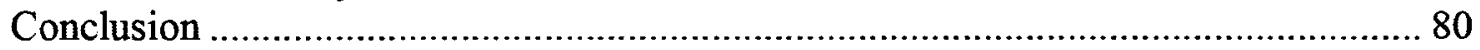

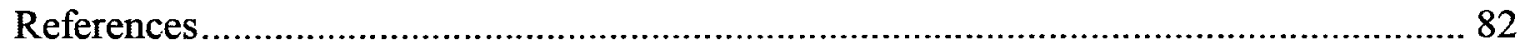

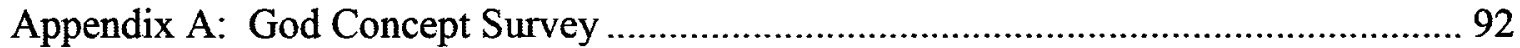

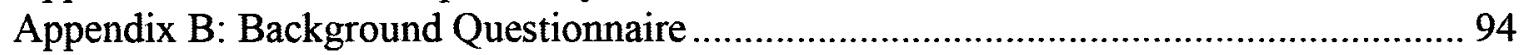

Appendix C: World Assumptions Scale ................................................................ 96

Appendix D: Multidimensional Locus of Control Scales: God Control Revision ........... 99

Appendix E: Religious Problem-solving Scale ...................................................... 102

Appendix F: Liberalism \& Conservatism Scale (Revised) ......................................... 105

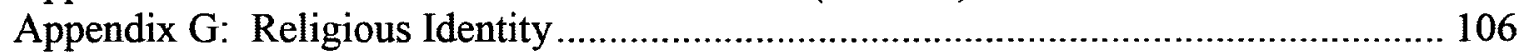

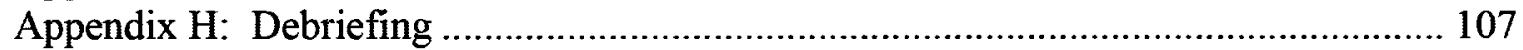

Appendix I: The 99 Attributes of Allâh ............................................................... 108 


\section{List of Tables}

Table 1 Summary of Items and Factor Loadings From Maximum Likelihood Factor Analysis for God Concepts …………............................................................ 35

Table 2. Gender differences in God Concepts .......................................................... 50

Table 3. Correlation of Age by God Dimensions ....................................................... 51

Table 4 Correlation of God Dimension with Assumptive World Variables..................... 53

Table 5. Correlation of God Dimension with Locus of Control Variables....................... 55

Table 6 Correlation of God Dimension with Religious Coping Variables ...................... 57

Table 7 Correlation of God Dimension with Religious Identity ...................................... 65 


\section{List of Figures}

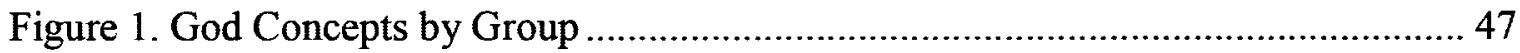

Figure 2. Punishing-Stern Dimension by Religious Group and Orientation. .................. 62

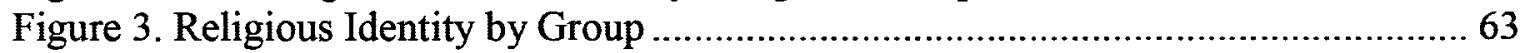


God Concepts. 1

\section{Introduction}

Public opinion surveys conducted in the United States suggest that $86 \%$ of American adults believe in God, and of these believers, $84 \%$ report that their religion is "very important" (57\%) or "fairly important" (27\%) in their lives (Gallup Poll, 2007). Similarly, according to a poll conducted by IPSOS, $84 \%$ of Canadians believe in God, and of these believers, $67 \%$ reported that their religious faith is very important to their daily life (IPSOS, 2002). Another fairly recent survey of Canadians indicates that $40 \%$ believe that God influences their lives (Bibby, 2001). Despite the apparent importance of religion in the lives of most people in the United States and Canada, very little research has examined the role these religious beliefs play in people's psychological life.

To a person of faith, nothing may be more central to his or her faith than the relationship he or she has with God (Owen, O'Grady, Smith, \& Richards, 2005). A religious person's relationship with God extends beyond believing in his existence, and likely includes ideas or beliefs about God's characteristics, abilities, power, warmth, expectations, and hopes. The relationship one has with God may be conceptually similar to how a person relates to other people (Pollner, 1989), an important part of which is one's perception of another person's characteristics. It seems reasonable then to assume that in maintaining a relationship with God, personal perceptions of what God is like will develop too.

To the extent that God is central to one's life, one's conceptualization of God may influence or relate to other assumptions or beliefs one holds about the world such as 
God Concepts. 2

one's belief in a just world, beliefs about the benevolence of others, and beliefs about personal control. It is the endeavour of this study to understand these relationships between a person's perception of God and his or her locus of control, religious coping, and assumptive world beliefs.

People for whom religion holds a central role probably have a clear idea of what God is like to them ${ }^{1}$. It is also likely that this conception of God differs from one person to the next. For instance, some perceive God to be loving and forgiving, whereas others perceive God to be punitive and wrathful. Some see God in masculine terms, thinking of God as powerful, demanding, and king-like, whereas others perceive God in feminine terms, such as healing, comforting, and nurturing. Given the importance of God in many people's lives, and the presumed power of the deity to influence the behaviour of millions of believers, it seems reasonable to propose that different conceptualizations of God will lead to quite different life goals, worldviews, and self-views. Understanding an individual's God concept might also shed light on how religious beliefs influence one's ability to cope with daily stress, relationships, adversity, and an impending death.

\footnotetext{
'The term "God" is being used as a generic term to encompass the various names and references that each religion or spiritual orientation uses to refer to the divine or deity, including Allâh, Higher Power, Yahweh, Ishwar, High God, the Sacred, etc. Furthermore, when referring to God as "he", this is done for convenience only and not to imply any specific sex or religious orientation.
} 
God Concepts. 3

Although stress, adversity, loss, and relationships each has been discussed at great length in the psychological literature, very little research has considered the role conceptualizations of God play in how one thinks about and responds to these issues. For example, a believer who has lost her spouse may feel that God is comforting her in her time of pain, testing her faith, or possibly punishing her for prior deeds. Which interpretation one adopts is likely to have a profound influence on one's grief, distress, and coping behaviour. The purpose of this thesis is to explore significant dimensions of what God is like, as represented by people of various faith groups, and to examine the extent to which these dimensions correlate with one's fundamental worldviews (or assumptive world), locus of control, and styles of coping.

\section{Religions and God}

A major component of religion is an attempt to explain the ineffable nature of God. God has revealed aspects of himself to his followers through is actions (or inactions), through messengers (e.g., prophets), and through individual communications (e.g., prayer). Ideas about God are also influenced by philosophy, culture, and daily happenings. People who believe in God (religious leaders in particular) use language to understand and describe God and to attribute meaning to his purported actions. Thus, although some have argued that God is not knowable in the sense that we know family and friends, most (if not all) believers have an understanding of what God is like (Scharfstein, 1993). These perceptions of God are likely shaped by the holy text one adopts, one's culture, history, and philosophy, as well as by leaders within one's religion. 
In this study, I focus on three different religious/spiritual groups: Christians, Muslims, and the New Age/Spiritual practitioners. Each of these groups has evolved out of distinctive historical, cultural, and experiential circumstances. These factors have influenced and formed collective conceptualizations of the identity, nature, or characteristics of God. In order to have a clearer understanding of how individuals of a specific religion/spiritual faith may conceptualize God, I will briefly summarize some of the significant issues and events within each faith which may have contributed to each group's understanding of what God is like.

\section{Christianity.}

The term Christian is derived from the Greek word, Christos, the anointed one. Thus, to be a Christian means that one is a follower of the anointed one, or Christ. According to Christians, Jesus, a carpenter until the age of 30 , became anointed by God while being baptised by John the Baptist (Luke 3:21-22). From this point Jesus began his ministry. Jesus, being a devout Jew, taught from the Hebrew Bible (later known as the Old Testament by Christians), and as such, believed that the Old Testament was divinely inspired and totally truthful scripture (Driscoll, 2008).

As part of their creed, Christians believe in a holy trinity. To Christians, God is made up of three entities or aspects combined into one. One of these aspects is God-theFather, who created the world and all that is in it. This aspect of God is not only the figurative father of all creation, he is also believed to be the literal father of Jesus. Jesus the Son of God, however, is also believed by Christians to be God (i.e., God incarnate), 
God Concepts. 5

who took the burden of humanity's sins upon himself and paid for those sins with his life. Since Jesus is also God, any description of Jesus is a description of God. The third aspect of God represented in this trinity is God-the-spirit. The Holy Spirit, which is still God, is the active presence of God in the world. Though the Holy Spirit has always been active in the world, the Spirit was promised by Jesus to come after his death to reside within each Christian to act as a helper (John 14:15-18). The Holy Spirit is believed to act upon the heart to bring a person into the Christian faith, and aids a Christian in living a righteous life in accordance to God's will.

After Jesus' death, scrolls depicting his life and death, as well as letters from the Apostles to the early Christian Church, began to be written. These scrolls would later be compiled into the Christian New Testament. Today's Christian Bible, with both the Old and New Testaments, give Christians an understanding of God, how the early Jews and Christians related to God, and serves as a guide for developing a daily relationship with God (Odebode, 2007). For many Christians, Jesus is God who became mortal (John 8:58; John 10:30); therefore, to know Jesus is to know God. Jesus' teachings emphasized a loving relationship with God and toward other people (Cavey, 2007).

For the Christian, a personal relationship with God is inferred as God in the Bible refers to himself as "Father" (for example, Deuteronomy 32:6, Psalms 89:26, and 
God Concepts. 6

Ephesians 4:6, New International Version ${ }^{2}$ ). However, which type of father God is, with his various attributes, is open to interpretation. For example, God is shown to be loving (Psalm 17:7, Romans 5:8, New International Version), to be merciful (Deuteronomy 4: 31, Ephesians 2:4, New International Version), and guiding (Psalms 25:9, James 1:5, New International Version). A father with these characteristics may be seen as an authoritative parent, loving and guiding his children. Yet God is also described in the bible as controlling (Isaiah 46:9-11, Acts 27:6, New International Version), wrathful (Deuteronomy 9:19, Colossians 3:6, New International Version), and jealous (Exodus 20:5, 1 Corinthians 10:22, New International Version). A father with these characteristics may be seen as an authoritarian parent, stern and strict with his children.

While both Old and New Testaments use similar language in describing God, and many theologians point out that the God depicted in both books are one and the same, many Christians view the Old Testament and the New Testament as entirely separate works (Johnson, 2009). The God of the Old Testament is often viewed as quick to anger and wrathful, whereas the God of the New Testament is one of love and tolerance (Hefner, 1998). Christians differ in the extent to which they view God as being loving and tolerant or wrathful and controlling. Some Christians believe that God loves them yet will punish them for transgression. For example, after the terrorist attacks of September

\footnotetext{
${ }^{2}$ For clarification that God is depicted in both the Old and New Testament similarly, the verses cited are deliberately from both Testaments.
} 
God Concepts. 7

11, 2001, two well-known Christian preachers (Jerry Falwell and Pat Robertson) were quoted as saying that the attacks were part of God's punishment on America (Ferguson, 2007). Other Christians believe that God loves and does not punish believers for transgressions.

Islam.

The term Islam means "peace" and "to submit to the law of Allâh" (Koenig, 1998). These laws were revealed to Mohammad, whom Muslims believe is the last prophet of God. Mohammad, a merchant by trade, began to have visions of the archangel Gabriel who instructed him to "read". To "read" meant that Gabriel would recite text to Mohammad who in turn would repeat it back, word-for-word until Gabriel was satisfied with Mohammad's accuracy. This "reading" took over 23 years to complete and the compilation of these readings became known as the "the recitation" or in Arabic, the Qur'an.

The Qur'an provides detailed instructions for Muslims on how to live correctly in accordance to God's Laws (Islahi, 2006). It is only through the complete submission to God and obedience to God's laws that a Muslim can achieve eternity with God. Through the Qur'an, Muslims not only derive their theology, but also the principles and institutions for their public lives (Koenig, 1998).

The Qur'an is focused on God and his laws for humans. Though the Qur'an teaches that Allah is beyond comprehension, the Qur'an does give examples of his attributes. Muslims found 99 names (or attributes) of God (see Appendix I for full list) in the Qur'an 
God Concepts. 8

(such as Ar-Rahman, the Compassionate, and Al-Qahhaar, the Subduer), which if emulated, "can establish a correct and sound relationship with God" (Islahi, 2006). There are four central teachings in the Qur'an: that God created humans (32:7, The Holy Qur'an), God sustains humans (10:31, The Holy Qur'an), God guides human lives (2:272, The Holy Qur'an), and God will judge all humans (19:93-98, The Holy Qur'an). According to Ward (1998), Islam is built upon the prophetic knowledge of Judgement Day, and that judgement is a central concern of God. God is all merciful to his faithful followers and ruthless in his judgement to all others. For a Muslim, every aspect of daily life revolves around his or her relationship as a submissive servant to the Supreme Sovereign, God, and submitting to God's Law in order to be counted as one of his faithful followers on Judgement Day.

In the Qur'an, each chapter (or Surahs) begins with the constant reminder that God is Most Gracious and Ever Merciful to his faithful followers. God is seen as a Supreme Sovereign over all things (Ciaravino, 2001). As Supreme Sovereign, God is separate from his creations, caring for his faithful followers who will share eternity with him. However, for those who displease God, he deals harshly. According to the Qur'an, God is capable of doling out punishment as he sees fit (64:9, The Holy Qur'an). 
God Concepts. 9

Although Christians and Muslims use similar terms for describing the attributes of God (for example, both religions believe that God loves ${ }^{3,4}$ and that God judges ${ }^{5,6}$ ), the attributes that are emphasized will likely differ by religion. To illustrate, both the Qur'an and the Bible make reference to God's love, but also acknowledge the existence of hell a place of punishment, devoid of God. Although "love" and "hell" appear in a number of verses in each of these religious texts, they appear more often (relatively) in the Qur'an. Using the New International Version Bible and Hilali-Khan translation of the Noble Qur'an, I found 14 references to "hell" in the 31,173 verses of the Bible $(0.04 \%)$ but 1195 references to "hell" in the 6,666 verses of the Qur'an (18\%). "Love" was mentioned 697 times in the Bible (2.24\% of verses), but 362 times in the Qur'an (5\% of verses). Thus, it would not be surprising if Muslims and Christians differed in the emphasis each group placed on God as punishing and loving.

3 "This is how god showed his love among us; He sent his one and only Son into the world that we might live through him". (1 John 4:9, New International Version).

4 “...Verily, Allâh loves those who frequently turn (to Him) with repentance and He loves the strivers to purification of themselves." (2:222, The Holy Qur $\square$ ân). S "And I heard the altar respond: "Yes, Lord God Almighty, true and just are your judgments." (Revelations 16:7, New International Version).

6 "Is (there still anyone to say that it is) not Allâh the Best of Judges." (95:8, The Holy Qur $\square$ ân). 
God Concepts. 10

New age/Spirituals.

To understand a New Age/Spiritual person's view of God, one must first understand the basic structure of the belief itself. The term New Age has gained attention in the past two decades; however, a complete understanding of the principles behind the New Age philosophy remains ambiguous (Hanegraaff, 1998). This is largely due to the fact that the New Age system is not an organized religion with a central leadership, nor does it have an official doctrine or holy text or a standard of practice to follow (Redden, 2002). The term New Age refers to a wide range of beliefs including those derived from astrology, Eastern thinking (e.g., Buddhism), and humanistic psychology (Granqvist, Ivarsson, Broberg, \& Hagekull, 2007). Some new age/spiritual practitioners believe in reincarnation, that God is a state of higher consciousness, or that God is a conglomerate of all souls (in other words, each person's soul is a fragment of God) (Hanegraaff, 2007). As a disorganized group, adherents pick and choose their beliefs to suit individual preferences and experiences.

As New Age philosophy is one of self-improvement and enlightenment and since some practitioners believe they are a fragment of God, the focus tends to be on God's positive attributes. Beverly Gaylean, a psychologist and proponent of New Age philosophy, has been quoted as saying that "...we all have the attributes of God...the perfect love, the perfect wisdom, the perfect understanding, the perfect intelligence..." (as quoted in Groothuis, 2006, p 14). Many of the views of God adopted by institutional religions, such as judging and wrathful, are rejected by New Age followers on the basis that the concepts have been corrupted in order to control individuals (Bednarowski, 1995) 
God Concepts. 11

or that such anthropomorphic views of God limit the vastness of the Divine (Hanegraaff, 2007). According to Hanegraaff, conceptualization of God by New Age practitioners generally reflects an "aversion to rigid, doctrinal definitions" (2007, p 183). Some scholars have suggested that New Age followers are attributing characteristics to God that they also would use to describe themselves (similarly to the findings of young adults conceptualizing God similarly to how they view themselves; Buri \& Mueller, 1993; Dickie, Ajega, Kobylak \& Nixon, 2006; Kirkpatrick \& Shaver 1990).

\section{Conceptualizations of God in General}

People use a variety of terms to describe what God is like to them. Most believers share an underlying core set of perceptions of God's character, or as Lach (1966) describes, a "skeletal core of God". For example, most believers see God as the creator of all things; He is all-knowing and all-seeing, and has supernatural powers. Though most believers may share the belief in the "skeletal core of God", they may differ in their conception of other aspects of his character. Spilka, Armatas, and Nussbaum (1964) attempted to capture the breadth of these individual differences in God concepts. They developed a list of adjectives that represented the Christian conception of God by asking undergraduate nursing students and middle-aged Methodist Sunday school attendees to describe "the nature of God". The authors used the terms offered by their participants to create an inventory of adjectives with terms such as wrathful, loving, jealous, forgiving, critical, and divine. A relatively homogeneous sample of girls from an all-girl Catholic college were then asked to rate the extent to which each term reflected their conception of 
God Concepts. 12

what God was like. Factor analysis of these ratings yielded eleven dimensions including "Stern Father", "Supreme Ruler", and "Kindly Father". Stern Father, for example, is a dimension made up of adjectives such as "unyielding", "punishing", and "restrictive". These dimension and others have been used in various studies to look at differences among Christian denominations (Hammersla, Andrews-Qualls, \& Frease 1986; Noffke \& McFadden, 2001). For instance, Noffke and McFadden (2001) found that Evangelical Christians perceived God to be more vindictive, stern, and supreme than Catholics and Methodists, whereas Methodists perceived God to be more distant than Evangelical Christians and Catholics.

\section{Individual conceptualizations of God}

Although one might assume that people within a single faith group are likely to have similar conceptions of God, I still expect a fair degree of variability within faith groups. For instance, Gorsuch (1967) has argued for the uniqueness of each individual's conceptualization of God, noting that people often deviate from their religious training or upbringing. A number of studies suggest that meaningful differences in God concepts are found within Christian denominations (e.g., Benson \& Spilka, 1973; Gorsuch, 1968; Spilka et al., 1964). Spilka et al. (1964), for instance, found considerable variability in God images among their sample of students in an all-girl Catholic college.

Another source of adjectives describing God has come from Gorsuch (1967) who set out to identify replicable factors in the conceptualization of God. Starting with items from Spilka et al. (1964), Gorsuch attempted to relate God concepts to theoretical work 
God Concepts. 13

by Osgood, Suci, and Tannenbaum (1957) on the "measurement of meaning". For Gorsuch, the resulting factor analysis of 63 adjectives produced eight dimensions applicable to research on conceptualization of God, many of which were similar, but not identical, to those offered by Spilka et al (1964). Later, Schaefer and Gorsuch (1991) refined the adjective list to 47 words, finding eleven primary God concepts: Benevolent, Wrathful, Omni, Guiding, False, Stable, Deistic, Worthless, Powerful, Condemning, and Caring. These studies show that individualistic God concepts can be clustered into meaningful dimensions that can then be related to other concepts, such as self-esteem.

In light of the fact that more than 40 years has passed since the creation of the Spilka et al (1964) and Gorsuch (1967) lists, and the fact that these lists reflect a Christian perspective (and, as far as I can determine, have only been used in Christian samples), I have revised the lists by removing dated terms (e.g., mythical or righteous), revised gendered terms to be gender neutral (e.g. Kingly to Sovereign), and added terms relevant to other religious perspectives (e.g., charitable). Given that much of the list remains comparable to the earlier research, I still anticipate that major dimensions found in this earlier research (e.g., loving God, punishing God) will also emerge in my data. However, I can only speculate the extent to which other dimensions found in the earlier research will be reproduced in a more multicultural university population from which I draw my sample. Furthermore, I expect that there will be differences between the faith groups in the degree of which they view God as being distant or close to his followers and how consistent they believe God is. In other words, even though the various faith 
God Concepts. 14

groups may use the same adjectives to describe God, they may differ in the extent to which they perceive that God possesses that characteristic. For instance, though the punishing dimension is expected to be seen in all faith groups, some groups may put more emphasis on this dimension than will others.

\section{Correlates of God Concepts}

Although the primary goal of the research is to understand the ways in which adherents of different faiths understand God, a secondary goal of the research is to relate these derived God concepts to other psychological constructs. Since very little is known about God concepts, and much of what is known is based on research with Christian samples, I have very little upon which to base predictions.

\section{Assumptive Worlds.}

Worldviews are general blueprints or implicit assumptions developed over several years of a person's life that guide how the person perceives the world in which he or she lives (Janoff-Bulman, 1989). Research has suggested that people have core beliefs about the social world, how the social world works, and how orderly and predictable is the world (Lerner, 2000). According to the Assumptive World theory (Janoff-Bulman, 1989), there are three significant and measurable components of a person's worldview upon which people differ: Meaningfulness, Benevolence, and Worthiness. For the proposed study, all three categories are of interest.

The first category, Meaningfulness, refers to a person's perception of the exterior world. People who believe in a meaningful world tend to believe: 1) that the world is just 
God Concepts. 15

insofar as good things happen to good people and bad things to bad people (Lerner, $2000)$; 2) that individuals are responsible for what happens to them; and 3) that the world is ordered and not a chaotic, random place (Janoff-Bulman, 1989). In respect to the assumption of order, according to Bibby, $86 \%$ of Canadian's polled believe there is a basic order to the world (2002). I speculate that people who perceive God to be punishing will tend to score higher on this dimension. People who perceive God to be punishing tend to see outcomes as largely due to God, and serving his purpose. As such, they are likely to see outcomes as ordered, just, particularly when one perceives that others are being punished by God for their sins. As Michael Marcavage, director of Repent America, was quoted as saying, with respect to the damage caused by Hurricane Katrina in New Orleans, "Although the loss of lives is deeply saddening, this act of God destroyed a wicked city" (Hurricane Katrina, 2005).

The Benevolence dimension in Janoff-Bulman's model is comprised of benevolence of people and the benevolence of the impersonal world. According to Janoff-Bulman (1989), people differ in the extent to which they believe that people and the material world are generally good. It is speculated that an individual who sees God as controlling and stern, similar to traditional Christianity (Gorsuch, 1968), will see the world as malevolent, rather than benevolent.

The final component, Worthiness of Self, refers to self-esteem. Prior research suggests that people's conceptions of what God is like are related to how they see themselves. If people do not see themselves as worthy of love (have low self-worth), then 
God Concepts. 16

they are unlikely to see God as loving and nurturing (Benson \& Spilka, 1973). In fact, Benson and Spilka (1973) found that those who perceived God to be loving tended to have high self-esteem, whereas those who perceived God to be punishing tended to report lower self-esteem. Dickie et al (2006) found similar results for male students, but found no significant correlation for female students.

Just as worldviews develop over many years, a person's religious and spiritual life also develops across a lifespan and becomes part of the psychological development of that person (Hill, Pargament, Hood, McCullough, Swyers, Larson, \& Zinnbauer, 2000). Although not part of Janoff-Bulman's model, God concepts may represent significant aspects of an individual's worldview. Studying a religious person's God concepts may shed light on his or her other assumptions about the world.

The fundamental worldviews are important because they represent the lens through which people view and interact with people, situations, and the material world. For a religious or spiritual person, their assumptions and beliefs about God may likewise influence how they understand and interact with the world. As Pargament put it, for people who are religious, "virtually every encounter, ordinary and extraordinary, stressful and non-stressful, is to be understood and experienced with the sacred in mind" (Pargament, 1997, p. 155). With that in mind, it is important to relate how people think about God to their other fundamental beliefs and assumptions. 


\section{Locus of Control.}

Locus of control (LoC) refers to the generalized expectancies that people hold about the root cause of events in life (Welton, 1999). More specifically, a person with an internal LoC tends to perceive outcomes as largely determined by one's own behaviour, whereas a person with an external locus of control tends to view outcomes as not being contingent on one's own actions. Recognizing that non-contingency might reflect various loci of control, Levenson (1973) revised the original locus of control scale (Rotter, 1966) to draw a distinction between chance as an external locus and the external control dimension that she termed "powerful others". This latter dimension is defined as one's tendency to perceive events as in the hands of powerful others (e.g. parents, professionals, a deity).

A variety of studies using different populations has attempted to understand a religious person's locus of control. At the core of religion is the issue of control (McIntosh, Kojetin, \& Spilka, 1985). For example, to a Protestant Christian, one of the steps required for salvation is to put one's life into the hands of God. As, Koenig, McCullough \& Larson (2001, p. 100) state, "While believing that God is in control might at first suggest an external locus of control, this is actually not the case". Most studies that Koenig et al. reviewed reported a positive and significant correlation between religiousness and internal locus of control. Findings with respect to other Locus of Control dimensions are less clear. Geist and Bangham (1980), using Rotter's LoC scale, found that Catholics reported higher external locus of control scores than Protestant participants did. They speculated that this was because Roman Catholics appear to be 
God Concepts. 18

guided more by the laws of the Vatican whereas Protestants are guided by their own personal beliefs. Pargament, Tyler, and Steele (1979) found that people with high intrinsic religious motivation (i.e., those who "live" their religion) showed lower sense of control by powerful others and lower chance perceptions than individuals who were extrinsically motivated (i.e., those who are religious for instrumental reasons, such as improving one's social image in the community by attending church). Others, however, have found no significant relationship between Christian religious belief and locus of control (Ritzema, 1979), at least as conceptualized by Rotter (1966) and Levenson (1973).

Because the Powerful Others dimension introduced by Levenson (1973) does not sufficiently capture the notion of giving control to God, Welton and colleagues (1996) added several God-related items to Levenson's LoC measure. The resulting God dimension of the Locus of Control scale refers to a belief that things happen according to God's plan or purpose. To make it clear that the Powerful Other dimension does not include God as a powerful other, Welton et al. (1996) revised two ambiguous items on the Powerful Other dimension to make it clear that the "Others" referred to in these items were people. Thus, consistent with the original intent, Powerful Other in Levenson's measure refers to perceiving the outcome as due to someone more powerful than self, (e.g. an airline pilot landing a jet safely). Welton et al. (1996) reported that the LoC God Control dimension is statistically independent of Internal, Chance, and Powerful Others dimensions, and reported that people scoring high on measures of religiosity, and those 
God Concepts. 19

who adhere to a literal interpretation of the Bible score higher on the LoC God dimension. I will use the Welton et al. (1996), revision of the LoC measure in the proposed study to assess control beliefs.

To my knowledge, only one study has examined the relation of control beliefs with God concepts (Benson \& Spilka, 1973), and this research used Rotter's scale. Though Benson and Spilka had initially hypothesized that the perception of God as controlling would relate to an external LoC, they actually found that it was not related $(r=.02)$. However, external LoC was significantly and negatively correlated with Loving-Kind God $(r=-.28, p<.01)$, and positively related with Allness (which includes the perception that God is infinite, absolute, unchanging, powerful and wise; $r=.18, \mathrm{p}<.05$ ), and Vindictive God $(r=.23, p<.01)$ scales. Given that the external dimension of Rotter's scale has now been subdivided into a Chance dimension, Powerful Others, and God Control dimension, it is unclear how Benson and Spilka's findings should be interpreted. As there are no other current studies examining the relationship between locus of control and God concepts, exploring this should further add to our understanding of a religious individual and his or her loci of control.

\section{Religious Coping.}

The coping process has increasingly received the attention of personality researchers as well as psychology of religion researchers (for an overview, see Harrison, Koenig, Hays, Eme-Akwari, \& Pargament, 2001). Coping is defined as "constantly changing cognitive and behavioural efforts to manage specific external and/or internal demands 
God Concepts. 20

that are appraised as taxing or exceeding the resources of the person" (Lazarus \& Folkman, 1984, p. 141). Coping can be conceived of as a set of strategies that people use to confront and respond to a threatening stimulus (e.g., a cancer diagnosis), or it can be seen as a general style of responding to a range of stimuli. My interest is with the extent to which people with different conceptions of God differ in how they generally respond to stressful situations. Pargament and colleagues (1988) have suggested that people who are religious differ in the extent to which and ways in which they involve God in their response to threat. According to Pargament (1997; Pargament et al., 1988), some people are self-directed in the sense that they take an active role in the problem-solving process whereas God is generally viewed as inactive. Pargament reports that those who use the self-directing style frequently tend to report higher self-esteem and a greater general sense of personal control (Pargament, 1997). In regards to God concepts, Maynard, Gorsuch, and Bjorck (2001) report that those who perceive God to be worthless tend to use more self-directed coping. Maynard et al. surmised that when a person sees God as worthless, he/she is more likely to rely on him or herself than to put trust in God. It is of interest to know whether this holds true across religions.

In contrast to the self-directed style, Pargament (1997) suggests that other people adopt a deferring coping style that indicates that they maintain a passive role, and expect God to take an active role in resolving their difficulties. In the Maynard et al. (2001) study described above, it was reported that those who favoured this way of coping tended to view God as benevolent, all-knowing, all-seeing, all-present, guiding, and stable. This 
God Concepts. 21

suggested to the authors that those individuals were willing to hand over complete control to a God who they believed cared for them, has the power to know and guide them, and the ability to act on their behalf. Even so, Pargament states that the deferring style is associated with poorer competence such as lower sense of personal control, chance locus of control, and lower self-esteem.

The third style proposed by Pargament (1997) is termed collaborative. Those adopting a collaborative coping style tend to perceive a partnership with God where the individual works with God to resolve the threat. Pargament (1997) reported that those who adopt a collaborative style tend to report higher self-competence. Similar to the selfdirected approach, collaborative individuals tend to have a greater sense of personal control, a lower chance-locus of control, and greater self-esteem (Pargament, 1997). In the Maynard et al. study, those adopting a collaborative coping style tended to view God low on their Worthless dimension, but report no significant positive correlations between other God concepts, such as Benevolent, Guiding, and Stable. In review of the God dimensions Maynard et al. (2001) used in their study, the Loving dimension, which I predict will be one of the dimensions this study will reveal, is absent. Had there been such a dimension, it is possible that there would have been a significant result.

\section{Liberal and Fundamental Religious Orientations.}

Research on God concepts has noted that there are denominational differences among Christians in how God is perceived (e.g., Noffke \& McFadden, 2001). However, given that there are more than 1000 recognized Christian denominations in North 
America (Robertson, 2006), and a large variety within other faith groups, it makes little sense to compare denominations one at a time. Rather than comparing denominations, I will relate God concept dimensions to the extent to which individuals perceive themselves to be liberal or fundamentalist within their religion.

Though some scholars argue that the term fundamentalist should only apply to the American religious movement (Marsden, 1990), others suggest that the characteristics of the fundamentalist movement may be applied to other religions (Pinnock, 1990). According to research, fundamentalist movements are found in many religions, such as Buddhism, Christianity, Hinduism, Islam, Judaism, neo-Confucianism, and Sikhism. Fundamentalist movements are found around the globe (Emerson \& Hartman, 2006). Though sociologists have identified fundamentalism around the globe, quantitative studies of fundamentalism tend to focus on American Christians, typically Protestant, rather than look at individuals from other religions. The proposed definition of fundamentalism is an adherence to traditional values and dogma (Martin, 1990), is resistant to the effects of culture (Breault, 1989), believes in the inerrancy of their holy texts and is theologically centred (Emerson \& Hartman, 2006). Liberalism is considered more culturally adaptive, anti-dogmatic, and human-centred. Human-centred refers to the doctrine's focus being on individual (such as the individual's right to interpret and to reject aspects of the religious text for him or herself). For instance, liberal protestant churches often support members who take different positions on a range of moral issues, including gay marriage and abortion. This may reflect a concept of God as being passive 
God Concepts. 23

and supportive. On the other hand, the Nazarene Church, a fundamentalist denomination, tries to convince its members of a single position on moral issues, which may be reflected in the view that God is judging and rigid.

Though the terms conservatism and fundamentalism are often interchangeable in the literature, for this paper, however, there will be a distinction. According to Martin (1990), although there is an overlap with the two terms, this does not necessarily mean that they are interchangeable. Fundamentalism is similar to conservatism in that both favour tradition, which refers to culturally defined beliefs and customs. The key separation between the two terms is that fundamentalism is religious in nature, where supporters believe in the inerrancy of their holy text, and adherence to religious beliefs and customs. Though conservatism has philosophical underpinnings in Christian fundamentalism, and though the term is used within the realm of religion, it is also often used to refer to a political ideology. An individual maybe politically conservative yet may or may not be religious. To avoid confusion, I will refer to religious conservatism as fundamentalism. However, because "fundamentalism" has come to allude to negative stereotypes of narrowness, bigotry, radicalism, obscurantism and sectarianism (Pinnock, 1990), the less negative label of "conservatism" will be used on the questionnaires. In the current research, I do not mean to imply any of these stereotypes when I use the term "fundamentalism".

One way to measure liberalism and fundamentalism is to ask the participants how their religious denomination is recognized, liberal or fundamental, and how they view 
God Concepts. 24

themselves. A second alternative is to assess the extent to which the individual agrees with statements that reflect fundamentalist and liberal perspectives. In the present study, I used Stellway's (1973) Conservatism Scale and Liberal Scale, which ask participants to rate such statements as "all miracles happened just as the Bible says they did" (fundamentalist), or "science and religion are both equally good ways to find truth" (liberal). The instrument has been adapted to replace Christian terms (e.g., Bible) with appropriate terms for each religion.

\section{The Current Study}

In this research, I asked people from a variety of religious groups to rate a series of adjectives in terms of how descriptive the term is to their idea of what God was like. Using factor analysis, I derived a set of dimensions that reflect different aspects of God. Although it was unclear how many dimensions would emerge from the data, it was anticipated that one dimension would reflect a view of God as loving and one dimension would reflect a view of God as punishing. These two dimensions appear quite consistently in the existing literature (e.g., Benson \& Spilka, 1973; Gorsuch, 1968).

It was expected that the various religions would have a similar structure to each other, even though they may differ in the extent to which God was perceived on those dimensions. For example, the items assessing God's loving nature clustered together in all faith groups, even though not all faiths saw God as particularly loving.

To test if there were significant differences between the religions on the dimensions, multivariate analysis of variance (MANOVA) was conducted on the various God 
God Concepts. 25

dimensions. Significant effects were followed up with Scheffe post hoc tests. In addition to comparisons by faith group, I also correlated God concept dimensions with coping subscale scores, locus of control subscale scores, world assumptions subscale scores, and fundamentalism scale scores to explore connections between one's perception of God and these other psychological constructs.

\section{Hypothesis}

1. The first hypothesis is that those individuals who score higher on the Punishing God concept will likely score high on the World Assumption dimension of Meaningfulness of the world. The three dimensions of Meaningfulness (justice, control, and order) are likely to reflect the belief that God blesses good people (justice), that it is the individual's behaviour that affects the outcome (control), and that God created the world to be orderly (order). On the Benevolence dimension, the perception of a Punishing God is likely to be associated with low scores. In other words, individuals who see God as punishing will be less likely to see people or the material world as benevolent. For example, most Christian doctrine teaches that humans since Adam and Eve are born sinners and therefore innately bad. On the Self-worth dimension, the perception of a Loving God is likely to be associated with high scores. In other words, participants who see God as loving will more likely see themselves as worthy. In regards to Christianity, it is speculated that because the theology emphasizes that humans are created in God's image (Genesis 1:27), those who follow this theology will view humans as having an intrinsic value and worth 
God Concepts. 26

because if God is of great intrinsic value and humans are made in God's image, then humans too have a high intrinsic value (Hood, Hill, \& Williamson, 2005). The Bible suggests that God values humans highly (e.g., "I have loved you with an everlasting love; I have drawn you with loving kindness" (Jeremiah 31:3 NIV Bible). This example is Christian; I am unsure the extent to which other religions' Holy texts emphasizes humans' worth. It has been suggested that Hindus view mankind as manifestations of the impersonal Brahman, therefore without an individual self and self-worth (Chandramohan, 2007). It is speculated that if participants from other religions view their deity as loving, they too will feel a sense of self-worth. To test these hypotheses, I will conduct correlational analyses of God concept scale scores with World Assumption subscale scores within each religious group and with the sample as a whole.

2. The second hypothesis is that individuals who score high on Loving God dimension will tend to adopt a "God Control" LoC perspective. Locus of control is about one's perception of control over events in one's own personal life. For a religious individual, events may be perceived as being orchestrated and controlled by God. The question then becomes, what type of God would take active control over events in his follower's life? Unlike a punishing God who may allow individuals to fail in order to punish them, a God who is perceived as loving and compassionate to the needs of his followers, as well as nurturing and guiding, may be perceived as taking control over events in order to teach and protect his followers. For example, to many Christians, 
God is a father figure and for Muslims God is depicted as the Supreme Sovereign. Whether a loving father or a loving Sovereign, both roles may be seen as having similar characteristics. A loving sovereign may be protective of his dependents, guiding situations in order to protect them. This is similar of a loving father, guiding and protecting his children.

3. The third hypothesis is in regards to religious coping styles and their relation to various God dimensions. On the assumption that those who take a self-directed approach to coping do not believe that God can or will support them in times of stress, I anticipate that people who adopt a self-directing coping style will tend to view God as wrathful, distant, and unloving. On the assumption that those who prefer the deferring approach to coping defer to God out of fear of his might, power, and ability to control both events in one's life and how one responds, I anticipate those with a deferring coping style will tend to view God as Punishing. Finally, on the assumption that people who take a collaborative approach to coping tend to see God as a partner who guides, nurtures, and has compassion for his people, I anticipate that those who adopt a collaborative style of coping will tend to see God as loving. It is assumed that an individual who perceives God as loving would likely view God as active in the lives of his people.

4. The final hypothesis is that those who score higher on the fundamentalism measure, regardless of religion, will view God similarly as members of another religion's fundamentalist denomination. In other words, a Fundamentalist Christian is likely to 
God Concepts. 28

have a similar view of God (e.g., as loving), as does a Fundamentalist Muslim.

However, those who score higher on liberalism will not necessarily have the same views as those from other liberal sects in other religions. To test this, I will conduct multivariate analysis of God concept scale scores with fundamentalism and liberal scores within each religious group. 
God Concepts. 29

\section{Methods}

\section{Participants}

The participants were recruited from the Psych 1001/1002 Subject Pool at Carleton University, as well as from postings at various religious groups around campus and from various religions forum websites (for example Ummah.com, a Muslim forum). The proportion of participants from Carleton University was $88 \%$. All participants were volunteers, with the Carleton students receiving extra credit in an introductory psychology class in return for their participation. Of the 1161 participants who responded to the survey, 288 classified themselves as currently Christian-Catholic, 212 classified themselves as Christian-non-Catholic (which henceforth will be regarded as Protestants), 73 classified themselves as Muslim, 62 classified themselves as New Age/Spiritual, and fewer than 43 classified themselves as Jewish, Hindu, Baha'i, or Buddhist. Two-hundred and seventy participants checked an "other" option, and when asked to specify, many of these indicated that they were agnostic, atheist, or follower of some unusual or fictitious religion (e.g., Jediism). For the purposes of analyses, I include only those religious groups represented by more than 50 participants (i.e., Catholic, Protestant, Muslim, and New Age/Spiritual; $\mathrm{N}=635$ ). Of the Catholics, $95.5 \%$ indicated that they were born into the Catholic faith. Of the Protestants, $84.4 \%$ indicated that they were born into the Protestant faith. Of the Muslims, $100 \%$ indicated that they were born into the Muslim faith. In contrast, only $16.1 \%$ of the New Age/Spirituals indicated that they were born 
God Concepts. 30

into their New Age/Spiritual faith; most followers were born Catholic (35.3\%) or Protestant (33.9\%).

The gender and age distributions within each of the four faith groups were similar, except that Muslims were more likely to be male $X^{2}(d f=3, N=635)=10.79, p<.05$. The Muslim sample was $58 \%$ female, with mean age of $22.0(S D=6.76)$. Of the Catholics, $72 \%$ were female, and their mean age was $21.6(S D=7.62)$. The Protestant sample was $77 \%$ female, with mean age of $22.1(S D=7.97)$. The New Age/Spiritual sample was $74 \%$ female, with mean age of $24.3(S D=9.14)$. There was a modest trend for New Age/Spiritual participants to be somewhat older, $(F(3,631)=2.18, p<.10)$.

\section{Procedure}

Carleton University psychology students were recruited over the Internet using the SONA system to participate in a study about perceptions of God. A recruitment notice was also posted on the WebCT for an introductory course on world religions offered by the Religious Studies program at Carleton. As well, posters were posted at various religious student clubs. Finally, a recruitment notice was posted on religious electronic bulletin boards (e.g., Ummah.com - Muslim Forum, virtualjerusalem.comJerusalem Forum). Those enrolled in Psychology 1001 or 1002 at Carleton were eligible for experiment credit towards their Psych 1001/1002 grade. No other compensation was available to participants. Participation was anonymous and voluntary. All questionnaires were administered using an online survey program (SurveyMonkey). 
God Concepts. 31

The first survey that was completed was the demographic questionnaire. In this questionnaire, I ask the participant to specify the religious group with which they currently affiliate. If the response to this question indicated the participant was Christian, references to the holy text in subsequent questions referred to the Bible. If the participant indicated that he or she was Muslim, references to God were replaced with "Allah" and references to the holy text were replaced with "the Qur'an" (etc.).

After the demographic questionnaire, participants completed a series of other questionnaires assessing their conception of God, world assumptions, locus of control, and religious coping. These measures are described in greater detail below. After all of the measurements were completed, participants received an online debriefing that described the purpose of the research.

\section{Measures}

\section{God Concepts.}

I initially developed a set of 91 adjectives that I found in various religious texts (the Qur $\square$ ân, the Vedas, and the Canon) which had been used to describe God, as well as terms from the Spilka et al. (1964) study and the Gorsuch (1967) study. This list then was presented to various religious leaders from the Ottawa community. The religious leaders were asked to give their opinion on the choice of adjectives and to contribute any new adjectives they deemed important. Although no new words were added to the list, words with multiple or ambiguous meanings were omitted (e.g., "mythical"), as were synonyms. Terms such as Omnipresent, Omnipotent, and Omniscient were removed because it was 
God Concepts. 32

expected that variance on these terms would be minimal (Hammersla, Andrews-Qualls, \& Frease 1986) and because unlike other terms, they reflect abilities. In addition, words that implied a gender, such as "fatherly", have been removed, as well as words that may have little meaning to younger participants (undergraduate students) such as "steadfastness." This yielded a list of 52 adjectives.

Though some previous research on God concepts had utilized the Q-sort methodology (a forced distribution method), I was concerned that this format would be difficult for my respondents. A pilot test confirmed that subjects had issues with the Qsort and were unanimous in their criticism that the Q-sort methodology forced them to place their responses into columns with which they did not agree. The religious leaders responded that by forcing them to distribute adjectives into a pile simply because I only allotted a certain number per column did not reflect their true perception of God. The participants resented the limitation that only a small number of adjectives could be labelled "just like God" and that some adjectives had to be categorized as "not at all like God". As well, rather than using anchors of "not at all" and "just like God", my pilot participants recommended that I use a format with anchors of "God is never like this" and "God is always like this".

The 52 adjectives were rated by each participant on a five point scale: $1=$ "God is NEVER like this", 2= "God is $\underline{\text { RARELY }}$ like this", $3=$ "God is SOMETIMES like this", $4=$

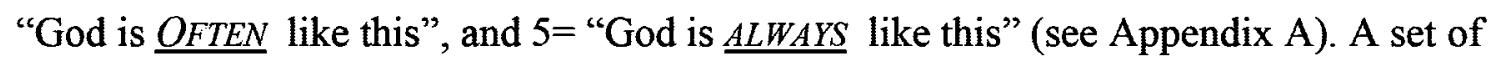
exploratory maximum likelihood factor analyses were conducted on the $52 \mathrm{God}$ 
God Concepts. 33

descriptors for the combined sample of Catholic, Protestant, Muslim, and New Age/Spiritual participants. Given the uneven distribution of participants across the four groups would give greater weight in the combined sample factor analyses to Catholics and Protestants, the data in the factor analyses were weighted by the inverse of their group's proportion (i.e., Catholic participants were weighted 0.55, Protestants were weighted 0.75, Muslims were weighted 2.17, and New Age/Spiritual participants were weighted 2.56).

Although the "eigenvalues $>1$ " rule suggested 8 factors, a scree test suggested that the data could be represented by four factors. Given the ambiguity, I examined obliquely rotated solutions for each of the five solutions between these two possibilities (retaining 4 factors, 5 factors, $\ldots 8$ factors). For solutions involving 6 or more factors, the last factor did not contain any items with primary loadings on that factor, and the second to last factor contained no more than two items with primary loadings on that factor (each loading <.50). The five factor solution (accounting for $49.7 \%$ of the common variance) yielded two weak factors with each item loading primarily on one of those two factors cross-loading on at least one other factor. Although cross-loading items are not necessarily problematic, they do introduce interpretational ambiguity if the factor has no unique identifiers. Thus, the five-factor solution was deemed sub-optimal.

In contrast to the 5 through 8 factor solutions, the 4 factor solution (accounting for $47.8 \%$ of the common variance) produced 4 interpretable factors, each with at least 5 primary loadings, although the last factor had 2 items with secondary loadings $>.30$ on at 
God Concepts. 34

least one other factor. Because one of the items ("unbiased") loaded $>.30$ on three of the four factors, it was dropped. The four factors were defined by their strongest loading items as "Kind-loving", "Punishing-stern", "Remote-Quiet", and "UnchangingUniversal". The factor pattern is provided in Table 1. For the calculation of dimension scores, I averaged all items loading $>.40$ on a factor. 
God Concepts. 35

Table 1

Summary of Items and Factor Loadings From Maximum Likelihood Factor Analysis for God Concepts $(\mathrm{N}=635)$

\begin{tabular}{|c|c|c|c|c|}
\hline & \multicolumn{4}{|c|}{ Factor Loading } \\
\hline & $\underline{I}$ & $\underline{\text { II }}$ & III & $\underline{\text { IV }}$ \\
\hline Kind & 1.051 & & & \\
\hline Loving & .969 & & & \\
\hline Compassionate & .945 & & & \\
\hline Charitable & .896 & & & \\
\hline Understanding & .877 & & & \\
\hline Supportive & .844 & & & \\
\hline Comforting & .840 & & & \\
\hline Patient & .824 & & .245 & \\
\hline Peaceful & .797 & & .204 & \\
\hline Giving & .787 & & & \\
\hline Nurturing & .731 & & & \\
\hline Guiding & .660 & & & \\
\hline Nearby & .539 & & -.221 & \\
\hline Responsive & .477 & & -.252 & \\
\hline Close & .436 & & -.212 & \\
\hline Convenient & .400 & .204 & & \\
\hline Punishing & & .745 & & \\
\hline Stern & & .727 & & \\
\hline Damning & & .704 & & -.216 \\
\hline Strict & & .701 & & \\
\hline Judging & & .684 & & \\
\hline
\end{tabular}


God Concepts. 36

(Table 1 continued)

\begin{tabular}{|c|c|c|c|c|}
\hline & \multicolumn{4}{|c|}{ Factor Loading } \\
\hline & $\underline{I}$ & $\underline{\text { II }}$ & $\underline{\text { III }}$ & $\underline{\text { IV }}$ \\
\hline Vengeful & & .678 & & \\
\hline Wrathful & & .650 & & \\
\hline Demanding & & .643 & & \\
\hline Cruel & & .624 & & \\
\hline Harsh & & .623 & & \\
\hline Dominating & & .623 & & \\
\hline Criticizing & & .604 & & \\
\hline Firm & & .598 & -.224 & .270 \\
\hline Spiteful & & .591 & & \\
\hline Rigid & & .565 & & \\
\hline Angry & & .553 & & \\
\hline Controlling & & .497 & & \\
\hline Tough & & .452 & & .367 \\
\hline Jealous & & .435 & & \\
\hline Sovereign/Kingly & & .278 & .391 & .208 \\
\hline Weak & & .383 & & -.287 \\
\hline Cold & & .368 & .283 & \\
\hline Remote & & & .703 & \\
\hline Quiet & & & .623 & \\
\hline Distant & & .241 & .612 & \\
\hline Passive & & & .603 & .248 \\
\hline Inaccessible & & & .599 & \\
\hline Unapproachable & & .291 & .463 & \\
\hline
\end{tabular}

(Table 1 continues) 
(Table 1 continued)

\begin{tabular}{lcccc}
\hline & \multicolumn{4}{c}{ Factor Loading } \\
\cline { 4 - 5 } & $\underline{\mathrm{I}}$ & $\underline{\mathrm{II}}$ & $\underline{\mathrm{II}}$ & $\underline{\mathrm{IV}}$ \\
\hline Aloof & & & .310 & \\
Unchanging & & & .239 & $\mathbf{6 6 7}$ \\
Universal & .291 & -.233 & & $\mathbf{5 2 1}$ \\
Absolute & .232 & & &. $\mathbf{4 5 4}$ \\
Unbiased & .348 & -.218 & .312 & .393 \\
Unyielding & & & .303 & .393 \\
\hline
\end{tabular}

Note: Response scale: $1=$ "God is Never like this" to 5="God is Always like this". Rotation Method: Promax with Kaiser Normalization. Loadings in bold indicate primary loadings used in computation of scale score. Item loadings $<|.20|$ are not printed. Four factors account for $47.8 \%$ of variance.

To examine the reliability of the four factors derived from the factor analysis (KindLoving God, Punishing-Stern God, Remote-Quiet God, and Unchanging-Universal God) a series of Cronbach alphas were run. For the Kind-Loving God factor, with 18 items, all four groups had similar and high alphas: Catholics' $\alpha=0.93$, Protestants' $\alpha=0.94$, Muslims' $\alpha=0.96$ and New Age/Spirituals' $\alpha=0.96$. For the 19-item Punishing-Stern God factor, Cronbach's alphas were also consistently high: Catholics' $\alpha=0.92$, Protestants' $\alpha=0.88$, Muslims' $\alpha=0.91$ and New Age/Spirituals' $\alpha=0.94$. For the Remote-Quiet God factor, with 6 items the alphas obtained were lower but still acceptable: Catholics $\alpha=0.73$, Protestants $\alpha=0.74$, Muslims $\alpha=0.78$ and New 
God Concepts. 38

Age/Spiritual $\alpha=0.80$. The alphas for the Unchanging-Universal God factor, with only 3 items, were generally lower and varied across groups: the Catholics had an alpha of 0.48 , Protestants 0.57, Muslims 0.76, and New Age/Spiritual 0.66. This last factor, Unchanging-Universal God, is of concern due to the wide fluctuations between the various groups' alphas.

\section{Background Questionnaire.}

Participants were given a demographic questionnaire (Appendix B) so such information as age, gender, current religious and/or spiritual affiliation, and level of education, could be ascertained. In addition to asking about current religious affiliation, participants were also asked about the religion they were born into, the extent to which they considered themselves to be liberal or conservative, and the extent to which their faith is regarded by others as liberal or conservative.

\section{World Assumptions Scale.}

The World Assumptive Scale (WAS; Janoff-Bulman, 1989; Appendix C) is a selfreport questionnaire assessing three different aspects of one's worldview: self-worth (e.g., "I am very satisfied with the kind of person I am"), benevolence (e.g., "The world is a good place"), and meaningfulness (e.g., "Life is too full of uncertainties that are determined by chance" (reverse-scored)). Although this instrument has been used with North American student samples (e.g., Harris \& Valentiner, 2002), to my knowledge, it has not been used in Muslim samples. 
God Concepts. 39

The scale has thirty-two items with six possible responses: $1=$ Strongly Disagree, 2= Disagree, $3=$ Somewhat Disagree, $4=$ Somewhat Agree, $5=$ Agree, and $6=$ Strongly Agree. In previous research, the instrument has demonstrated adequate reliabilities with Cronbach alphas 0.87 for the Benevolence subscale, 0.76 for Meaningfulness subscale, and 0.80 for Self Worth subscale (Jeavons \& Greenwood, 2007). In my study, the three subscales yielded somewhat lower but still acceptable reliability coefficients in each of the four groups. The Cronbach alpha for the Benevolence subscale (with 8 items) was .63 for Catholics, .66 for Protestants, .74 for Muslims, and .72 for New Age/Spirituals. The Meaningfulness subscale (with 12 items) yielded alphas of .73 for Catholics, .77 for Protestants, .81 for Muslims, and .77 for New Age/Spirituals. The Self-Worth subscale (with 12 items) yielded alphas of .65 for Catholics, .62 for Protestants, .80 for Muslims, and .74 for New Age/Spirituals.

\section{Multidimensional Locus of Control Scales: God Control Revision.}

The Multidimensional Locus of Control Scales (Levenson, 1973; Appendix D) examine the generalized expectancy to perceive events as being contingent on one's own behaviour (Internal control, or I) or as the result of forces beyond one's control, either by Chance (C) or by Powerful Others (PO). Welton et al. (1996) added eight new items to assess the God control dimension, and clarified two items on the Powerful Others dimension to make it clear that the powerful other is human. Each of the items is rated on a six point scale where $1=$ "Strongly Disagree," 2 = "Disagree," 3 = "Somewhat Disagree," 4 = "Somewhat agree," 5 = "Agree, 6 = "Strongly Agree." 
Reliability and validity of the Levenson (1973) scales have been established in numerous studies (Degelman \& Lynn, 1995; Pargament et al., 1987; Richards, 1991), and Welton et al. (1996) have indicated that the Cronbach's alpha of the God dimension to be in the range of .82 to .89 in samples recruited from a Christian college and a state university. In the present study, Cronbach's alphas for the Locus of Control - God scale (8 items) was .90 among Catholics, .91 among Protestants, .87 among Muslims, and .89 among New Age/Spirituals.

With respect to validity, Welton et al. (1996) reported that scores on the God Control dimension correlate strongly with religiosity and literal interpretation of the Bible. Welton et al. (1996) found a small negative correlation between the Internal Locus of Control scores and God Control scores in sample of students at a state university $(r=$ .17), and a weaker correlation in a small sample of students from a Christian liberal arts college $(r=.-01)$. In the present study, the magnitude of correlation between Internal Locus of Control and God Control varied by religious group, with the correlation highest among Protestants $(r=-.39, p<.001)$ and lowest among Muslims $(r=.03, n s)$. Replicating Welton et al.'s (1996) finding that God Control is positively correlated with literal interpretations of the Bible (i.e., fundamentalism), I observed that among Catholics, Protestants, and Muslims, the extent to which one believes God is in control of important outcomes is positively correlated with the fundamentalism $(r \mathrm{~s}=.62, .80$, and .67 , respectively; $p$ s $<.001)$. 
God Concepts. 41

Religious Coping Strategies.

The Religious Problem-solving Scale (RPS; Pargament et al., 1988; Appendix E) assesses the extent to which God plays an important role in how one copes with difficulties and problems. It measures three religious based styles: collaborative, selfdirecting, and deferring. The RPS is comprised of three separate subscales designed to discriminate between the degree of responsibility of either self and God in problemsolving. The scale has 36 items, which are scored from $1=$ Never, $2=$ Hardly Ever, $3=$ Neutral/No Opinion, $4=$ Often, and $5=$ Always. In previous studies, both internal consistency and test-retest reliability were found to be high (e.g., Thurston, 1999). For instance, Thurston (1999) reported Cronbach's alpha coefficients for the three subscales, self-directing, collaborative, and deferring were $.91, .93$, and .89. In the present study, Cronbach's alphas for the three subscales of Religious Coping measure were consistently above .90 for each group.

Pargament et al. (1987) reported moderate to high intercorrelations between the three coping styles (collaborative with deferring $r=76$, collaborative with self-directive $r=-.61$, and self-directive with deferring $r=-.37$ ). The collaborative coping style correlated with deferring for all four groups (Catholics $r=.76, \mathrm{p}<.001$, Protestants $r=$ $.86, \mathrm{p}<.001$, Muslim $r=.54, \mathrm{p}<.001$, and New Age/Spiritual $r=.81)$. The collaborative coping style negatively correlated with self-directive for all four groups (Catholic $r=-.70, \mathrm{p}<.001$, Protestants $r=-.76, \mathrm{p}<.001$, Muslim $r=-.29, \mathrm{p}<.05$, and New Age/Spiritual $r=-.73, \mathrm{p}<.001)$. The deferring coping style was negatively correlated with self-directive in three of the groups (Catholic $r=-.53, \mathrm{p}<.001$, 
Protestants $r=-.68, \mathrm{p}<.001$, and New Age/Spiritual $r=-.68, \mathrm{p}<.001$ ) with Muslims having no significant correlation $(r=.08, n s)$.

Fundamentalism Scale.

The Christian Conservatism and Christian Liberalism Scales originally created by Stellway (1973) were developed to measure commitments to theological assumptions of conservative Christians and liberal Christians. Stellway described conservative Christians as viewing God as an all-wise, personal, and morally pure supernatural power, whereas liberal Christians viewed God in more natural terms rather than supernatural. For example, within a liberal Christian framework, orthodox notions of sin and punishment receive little attention, whereas the dignity and creative potential of humans are emphasized.

The Christian Conservatism Scale is made up of seven items that are individually rated on a six point Likert scale $(1=$ Strongly Disagree, $2=$ Disagree, $3=$ Neutral $/$ No Opinion, 4= Somewhat Agree, 5= Agree and 6= Strongly Agree). The scale consists of six positively worded statements and one negative. All seven response are added together to create an overall Christian Conservatism score ranging from 7 to 35 . Stellway did not supply any information on the reliability of the measure. However, Boivin, Darling and Darling (1987) reported an alpha of .86 for a six item version of the Christian Conservativism Scale.

For the present study, the scales have been modified in order to make them applicable to a broader range of religions and to reduce the redundancy of questions from 
God Concepts. 43

the two scales. It does not make sense to assess liberalism/fundamentalism among New Age/Spirituals. In general, this group is relatively unorganized and does not have a core religious doctrine of text. To make the instruments appropriate for non-Christian samples, references to the Bible have been replaced with the appropriate religious text (such as the Bible, Qur $a$ ân, Torah, etc.), and one question regarding Jesus Christ as the only son of God has been omitted (see Appendix F). The resulting scales have four items. Cronbach's alpha for the Fundamentalism scale was adequate in all three religious groups (alphas $>$ .81). Unfortunately, the Liberal subscale failed to produce adequate reliability coefficients (alphas $<.58$ ), therefore it will not be reported on further in this study. Scores on the Fundamentalism scale were correlated with the extent to which participants viewed their religious group as fundamental vs. liberal $(r \mathrm{~s}=.36, .50$ and $.47, p \mathrm{~s}<.001)$, but tended not to be correlated with how liberal or fundamental individuals perceived themselves ${ }^{7}$.

${ }^{7}$ Though the Fundamentalism measure was based on the definition of fundamentalism found in this paper, the direct question from the demographic questionnaire did not clearly define the term. It is being speculated that the participants used a more encompassing definition than what I had anticipated. A person may hold to the defined fundamentalist values, but in addition, their definition may include political issues as well. For example, the participant may view their religion as more conservative because it is against gay marriages or abortions. If the participant believes that gays should be Footnote continued on next page. 
God Concepts. 44

Religious Identity Scale.

The Religious Identity Scale assesses the degree to which the participants religious identity relates to other individuals from the same religion. A sample item is "I feel strong ties to other Christians". Each question used an 8-point response scale ranging from $1=$ Definitely Disagree to 8= Definitely Agree. (See Appendix G for further details).

The Religious Identity Scale showed a high Cronbach alpha for each religious group ranging from 0.91 to 0.96 . Fundamentalism score was positively correlated with Religious Identity scores in an overall correlation $(r=.68, p<.001)$. The three groups in which Fundamentalism orientation has been measured (Catholics, Protestants and Muslim) has indicated a positive correlation between Fundamentalism and their Religious Identity. Analysis indicates that Religious Identity is significantly related to Fundamentalism religious orientation (Catholics, $r=.33$, Protestants, $r=.52$, and Muslims $r=.53, p \mathrm{~s}<.001)$.

allowed to marry or believe in pro-choice, then they would view themselves less fundamentalist than their religion, while still subscribing to the defined characteristics of fundamentalism. 
God Concepts. 45

\section{Results}

\section{God Concept Dimensions}

A multivariate oneway analysis of variance (MANOVA) on the four God concepts indicated a significant group effect (Wilks' Lambda $=.83, F(12,1661)=10.25, p<$ .001). Before conducting follow-up ANOVAs on this multivariate effect, tests of homogeneity of variances and covariances were conducted. Given unequal sample sizes across the groups, it was important to test the MANOVA assumption that the covariance matrices of the four God concepts were consistent or homogeneous across the four religious groups. The Box $M$ test of this assumption indicated that the assumption did not hold $(M=206.92, F(30,175282)=6.76, p<.001)$. To assess the sources of heterogeneity, a series of pairwise Box $M$ tests were conducted (i.e., assessing whether the assumption was valid for Catholics and Protestants, Catholics and Muslims, Catholics and New Age/Spirituals, etc.). In each case, the test was significant or near significant, with the least heterogeneity between Catholics and Protestants (Box $M=24.68, F(10$, $972650)=2.45, p=.006$, where Tabachnick and Fidell $(2007$, p. 252) suggest that the appropriate criterion for heterogeneity is $p<.001$; all other Box $M$ tests were $>71, F$ 's $>$ $6.9, p \mathrm{~s}<.001)$. Interestingly, tests of the univariate ANOVA assumption of equal variances were generally in an acceptable range, with only one God concept (LovingKind) indicating heterogeneous variances across groups $(F(3,631)=6.15, p<.001)$. The variance on the Loving-Kind dimension did not differ among Catholics, Protestants, and Muslims but all groups did differ from New Age/Spirituals, who had a larger variance 
than the other groups. The heterogeneity in covariance matrices, together with the relative homogeneity of variances, suggests that the relations among God concepts differ significantly from one religious group to another. Therefore, it will be important to examine the correlations among God concepts separately for each religious group.

Follow-up oneway ANOVAs on each of the four concepts indicated significant differences among groups on the Loving-Kind dimension $(F(3,631)=23.43, p<.001)$, the Punishing-Stern dimension $(F(3,631)=6.70, p=.001)$, the Remote-Quiet dimension $(F(3,631)=5.19, p=.002)$, and the Unchanging-Universal dimension $(F(3,631)=$ $18.76, p<.001)$. With respect to the Loving-Kind dimension, Scheffé post-hoc tests indicated that Muslims considered God to be more Loving-Kind than all other groups, and that Catholics and Protestants considered God to be more Loving-Kind than New Age/Spirituals. For a visual representation, see Figure 1. With respect to the PunishingStern dimension, Scheffé post-hoc tests indicated that New Age/Spirituals considered God to be less punishing than all other groups (although the difference was marginal for Protestants). With respect to the Remote-Quiet dimension, Scheffé post-hoc tests indicated that Catholics considered God to be more remote than Protestants and Muslims. Finally, with respect to the Unchanging-Universal dimension, Scheffé post-hoc tests indicated that Muslims regard God as more unchanging than all other groups (although the difference with Protestants was marginal), Protestants see God as more unchanging than Catholics and New Age/Spirituals, and Catholics see God as more unchanging than New Age/Spirituals. 


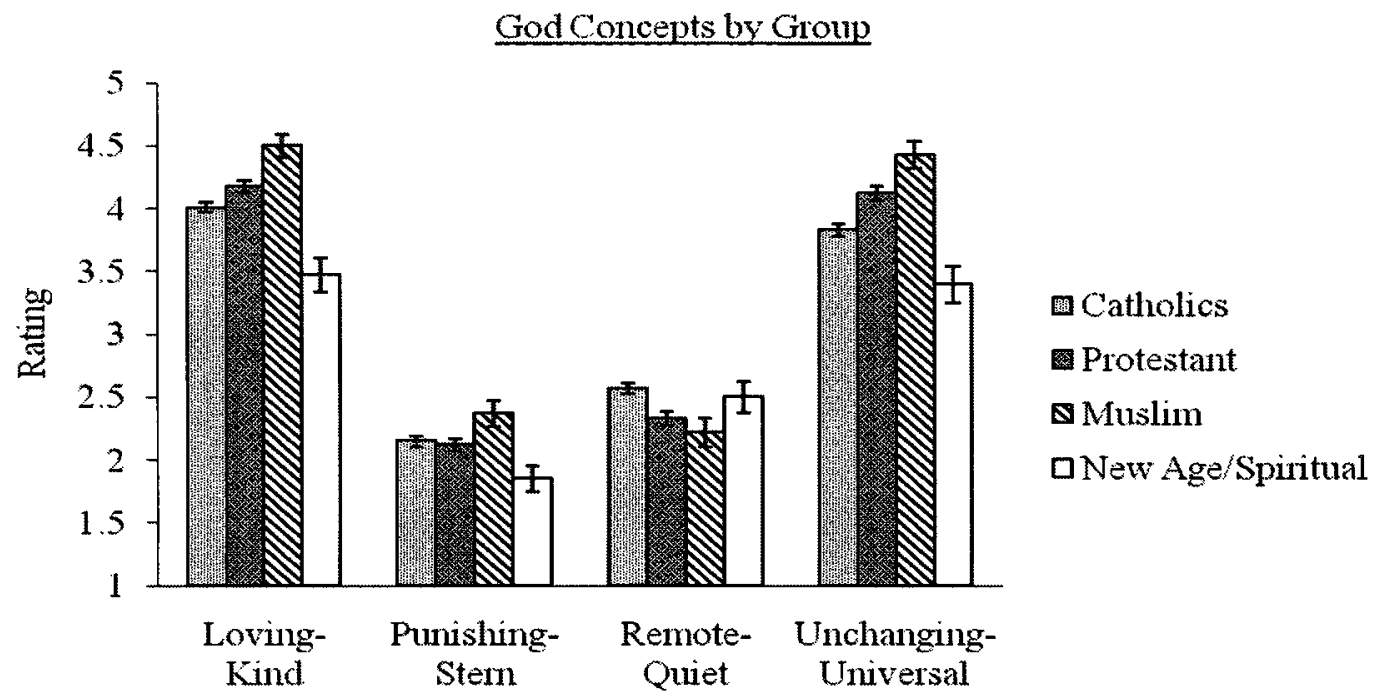

Figure 1. Mean God Concepts score for each group (+/- SE) for Catholics $(n=288)$, Protestants $(n=212)$, Muslims $(n=73)$ and New Age/Spiritual $(n=62)$ on five point scale $(1=$ "God is never like this" to $5=$ "God is always like this").

The heterogeneity of covariances in the MANOVA indicates that the correlations among the God concepts varied across group. Although Protestants and Catholics were quite similar in the pattern of correlations, Muslims were quite distinct. For instance, whereas the extent to which God is perceived as Loving-Kind is negatively correlated with the extent to which God is perceived to be Punishing-Stern among Catholics and Protestants ( $r \mathrm{~s}=-.30$ and $-.16^{8}$, respectively), these two concepts were positively

\footnotetext{
${ }^{8}$ For Protestants, when gender and age were partialled out of the correlation, the LovingKind and Punishing-Stern dimensions were no longer significant $(r=-12, n s)$.
} 
God Concepts. 48

correlated among Muslims $(r=.28, p<.05)$. Similarly, whereas the extent to which God is perceived to be loving is negatively correlated with the extent to which $\mathrm{He}$ is perceived to be Remote-Quiet among Catholics and Protestants ( $r \mathrm{~s}=-.46$ and -.65 , respectively), these concepts have no significant relation to each other among Muslims $(r=.02, n s)$. The correlation among God concepts was also somewhat different for the New Age/Spiritual group. The extent to which New Age/Spiritual participants viewed God as Unchanging-Universal was negatively correlated with the extent to which they perceived God to be Punishing-Stern $(r=-.27, p<.05)^{9}$, but these two concepts were positively correlated among Muslims $(\mathrm{r}=.25, \mathrm{p}<.05)$ and not at all correlated among Catholics and Protestants ( $\mathrm{rs}=-.07$ and .03 , respectively).

Though there are distinctions between the groups, there are also similarities. For all groups, the extent to which God is perceived as loving is positively correlated with Unchanging-Universal by all groups (Catholics, $r=.48, p<.001$, Protestants, $r=.51, p<$ .001 , Muslim, $r=.86, p<.001$ and New Age/Spiritual $r=.34, p<.01$ ). In addition, for all four groups, the Remote-Quiet dimension was positively correlated with PunishingStern God dimension (Catholics, $r=.47, p<.001$, Protestants, $r=.28, p<.001$, Muslim, $r=.57, p<.001$ and New Age/Spiritual $r=.48, p<.01)$.

${ }^{9}$ For New Age/Spiritual, when gender and age were partialled out of the correlation, the Unchanging-Universal and Punishing-Stern dimensions were no longer significant $(r=$.$24, n s)$. 
God Concepts. 49

I also explored whether God concepts varied as a function of gender by conducting a 2 (gender) by 4 (faith group) MANOVA on the four God Concept scores. The interaction between gender and religious groups on the composite DV was significant $($ Wilks' Lambda $=.96, F(12,1651)=2.09, p<.05)$. The main effect of gender on the God Concept composite DV was also significant (Wilks' Lambda $=.94, F(4,624)=9.30$, $p<001)$.

Since the multivariate interaction was significant, I examined the univariate interaction effects but found no significance results. This implies that some combination of God concepts differs across groups. Since the covariances are not homogeneous across groups, it is not appropriate to investigate the linear combination that is responsible for the significant multivariate effect.

Univariate analyses to follow-up the significant multivariate main effect of gender indicated that females viewed God as more Loving-Kind $(F(2,626)=30.47, p<.001)$, whereas males viewed God as more Punishing-Stern $(F(2,626)=8.01, p<.01)$, and Remote-Quiet $(F(2,626)=5.68, p<.05)$. The main effect was not significant for the Unchanging-Universal dimension $(F(2,626)=3.24, n s)$. For means and standard deviations for the four God concepts by genders, see Table 2 . 
Table 2.

Gender differences in God Concepts.

\begin{tabular}{lcccc}
\hline \multicolumn{1}{c}{ Dimension } & $\underline{2}$ & $\underline{S} \underline{\underline{M}}$ & $\underline{M}$ & $\underline{\mathrm{SD}}$ \\
\hline Loving-Kind & 4.16 & .69 & 3.94 & .95 \\
Punishing-Stern & 2.09 & .70 & 2.40 & .76 \\
Remote-Quiet & 2.38 & .78 & 2.60 & .98 \\
Unchanging-Universal & 3.99 & .92 & 3.86 & .96 \\
\hline
\end{tabular}

Note: For females, $n=459$, males, $n=176$.

I also explored whether God concepts varied as a function of age by conducting a correlation of God Concepts with age. The findings indicated small but significant positive correlations of age with Loving-Kind and Unchanging-Universal scores, and a small but significant negative correlation of age with Remote-Quiet scores (see Table 3 for correlation data). I then ran the same correlations by religious groups. Although not always statistically significant, the pattern of results was consistent with the overall pattern for Catholics and Protestants. Among Muslims, no age effects were evident. Among New Age/Spiritual participants, only one correlation stood out as distinct, and that was for the Unchanging/Universal dimension, such that older participants were more likely to see God as unchanging/universal. 
Table 3.

Correlation of Age by God Dimensions

\begin{tabular}{|c|c|}
\hline Group & Age \\
\hline \multicolumn{2}{|l|}{ Overall } \\
\hline Loving-Kind & $.07 *$ \\
\hline Punishing-Stern & -.03 \\
\hline Remote-Quiet & $-.13^{* *}$ \\
\hline Unchanging-Universal & $.08^{*}$ \\
\hline \multicolumn{2}{|l|}{ Catholic } \\
\hline Loving-Kind & .08 \\
\hline Punishing-Stern & .03 \\
\hline Remote-Quiet & -.11 \\
\hline Unchanging-Universal & .09 \\
\hline \multicolumn{2}{|l|}{ Protestant } \\
\hline Loving-Kind & $.24 * * *$ \\
\hline Punishing-Stern & -.03 \\
\hline Remote-Quiet & $-.15^{*}$ \\
\hline Unchanging-Universal & .06 \\
\hline \multicolumn{2}{|l|}{ Muslim } \\
\hline Loving-Kind & .03 \\
\hline Punishing-Stern & -.03 \\
\hline Remote-Quiet & .01 \\
\hline Unchanging-Universal & .05 \\
\hline \multicolumn{2}{|l|}{ New Age/Spiritual } \\
\hline Loving-Kind & -.01 \\
\hline Punishing-Stern & -.16 \\
\hline Remote-Quiet & -.15 \\
\hline Unchanging-Universal & $.25 *$ \\
\hline \multicolumn{2}{|c|}{ Note: $* * *$. Correlation is significant at the 0.001} \\
\hline level (2-tailed). ${ }^{* *}$. Cor & nificant at the \\
\hline 0.01 level (2-tailed). *. & significant at \\
\hline
\end{tabular}


God Concepts. 52

As both age and gender are significantly associated with at least some of the god concept scores, analyses described below were repeated covarying age and gender and any differences are noted.

Assumptive World

I anticipated (Hypothesis 1a) that participants scoring higher on the PunishingStern God dimension would tend to score high on the Meaningfulness subscale of the World Assumptions Scale. For Catholics, Muslim and New Age/Spiritual, there was a significant positive correlation between viewing God as Punishing-Stern and the Meaningfulness of the world ${ }^{10}$ (see Table 4 for correlations), while no significant correlation was observed among Protestants.

${ }^{10}$ For Catholics, when gender and age were partialled out of the correlation, the relationship between Punishing-Stern dimension and Meaningfulness was no longer significant $(r=.11, n s)$. 
God Concepts. 53

Table 4.

Correlation of God Dimension with Assumptive World Variables.

\begin{tabular}{|c|c|c|c|}
\hline & Worthiness & Benevolence & Meaningfulness \\
\hline \multicolumn{4}{|l|}{ Overall } \\
\hline Loving-Kind & .05 & $.24 * * *$ & -.06 \\
\hline Punishing- Stern & $.09 *$ & .03 & $.12 * *$ \\
\hline Remote-Quiet & $.14 * * *$ & -.05 & $.21 * * *$ \\
\hline Unchanging- Universal & .04 & $.15^{* * *}$ & -.06 \\
\hline \multicolumn{4}{|l|}{ Catholic } \\
\hline Loving-Kind & .09 & $.26 * * *$ & .03 \\
\hline Punishing- Stern & $.13 *$ & -.01 & $.13 *$ \\
\hline Remote-Quiet & .07 & $-.14^{*}$ & .07 \\
\hline Unchanging- Universal & .05 & $.22 * * *$ & .03 \\
\hline \multicolumn{4}{|l|}{ Protestant } \\
\hline Loving-Kind & -.07 & $.15^{*}$ & $-.26 * * *$ \\
\hline Punishing- Stern & -.10 & -.10 & -.07 \\
\hline Remote-Quiet & .10 & $-.14^{*}$ & $.19 * *$ \\
\hline Unchanging- Universal & .00 & .05 & $-.18 * *$ \\
\hline \multicolumn{4}{|l|}{ Muslim } \\
\hline Loving-Kind & .17 & .21 & .02 \\
\hline Punishing- Stern & $.30^{* *}$ & $.25 *$ & $.30^{* *}$ \\
\hline Remote-Quiet & $.35^{* *}$ & .18 & $.50 * * *$ \\
\hline Unchanging- Universal & .14 & .22 & -.001 \\
\hline \multicolumn{4}{|l|}{ New Age/Spiritual } \\
\hline Loving-Kind & .22 & $.53 * * *$ & .14 \\
\hline Punishing- Stern & .14 & .21 & $.35^{* *}$ \\
\hline Remote-Quiet & .11 & .10 & $.28^{*}$ \\
\hline Unchanging- Universal & .17 & .24 & -.01 \\
\hline
\end{tabular}

Note: ${ }^{* * *}$. Correlation is significant at the 0.001 level (2-tailed).

**. Correlation is significant at the 0.01 level (2-tailed).

*. Correlation is significant at the 0.05 level (2-tailed).

I also hypothesized (Hypothesis $\mathrm{Ib}$ ) that those who perceived God to be Punishingstern would tend see the world as malevolent (i.e., score low on Benevolence subscale of 
God Concepts. 54

the WAS). Across the four religious groups, there were no significant negative correlations of Punishing-stern perceptions of God with the Benevolence subscale ( $r \mathrm{~s}$ ranging from -.10 to +.25 ).

The final portion of this hypothesis concerns the relation of self-worth to perceptions of God as Loving-Kind. Across the four groups, no significant correlations were observed between these two constructs ( $r$ s ranging from -.07 to +.22 ).

\section{Locus of Control}

In Hypothesis 2, I had hypothesized that to the extent that one perceived God as Loving-Kind one would also possess God-centred Locus of Control. I tested these hypotheses by correlating the God concepts (with the sample as a whole and within religious groups) to the Locus of Control subscale scores. The results, given in Table 5, indicate that in all four groups, perceiving God as Loving-Kind is associated with a greater God-centred LoC. 
Table 5 .

Correlation of God Dimension with Locus of Control Variables

\begin{tabular}{|c|c|c|c|c|}
\hline & Internal & Chance & God Control & $\begin{array}{c}\text { Powerful } \\
\text { Other }\end{array}$ \\
\hline \multicolumn{5}{|l|}{ Overall } \\
\hline Loving-Kind & $-.11 * *$ & -.04 & $.61^{* *}$ & -.07 \\
\hline Punishing- Stern & -.01 & $.13 * *$ & $.11 * *$ & $.22 * * *$ \\
\hline Remote-Quiet & $.14^{* * *}$ & $.22 * * *$ & $-.34 * * *$ & $.24 * * *$ \\
\hline Unchanging- Universal & $-.08^{*}$ & $-.09 *$ & $.46 * * *$ & $-.10^{*}$ \\
\hline \multicolumn{5}{|l|}{ Catholic } \\
\hline Loving-Kind & -.09 & .06 & $.54 * * *$ & -.02 \\
\hline Punishing- Stern & -.05 & .10 & -.05 & $.19 * *$ \\
\hline Remote-Quiet & .04 & .05 & $-.32 * * *$ & .12 \\
\hline Unchanging- Universal & -.09 & .03 & $.28 * * *$ & .03 \\
\hline \multicolumn{5}{|l|}{ Protestant } \\
\hline Loving-Kind & $-.25 * * *$ & $-.23 * *$ & $.65^{* * *}$ & $-.22 * *$ \\
\hline Punishing- Stern & .02 & -.02 & .10 & .07 \\
\hline Remote-Quiet & $.16^{*}$ & $.27 * * *$ & $-.45 * * *$ & $.24 * * *$ \\
\hline Unchanging- Universal & $-.17^{*}$ & $-.22 * *$ & $.54 * * *$ & $-.23 * *$ \\
\hline \multicolumn{5}{|l|}{ Muslim } \\
\hline$\overline{\text { Loving-Kind }}$ & .21 & .06 & $.57 * * *$ & .003 \\
\hline Punishing- Stern & .10 & $.37 * *$ & $.27 *$ & $.40^{* *}$ \\
\hline Remote-Quiet & .19 & $.51 * * *$ & -.03 & $.41 * * *$ \\
\hline Unchanging- Universal & .19 & .02 & $.51 * * *$ & -.04 \\
\hline \multicolumn{5}{|l|}{ New Age/Spiritual } \\
\hline Loving-Kind & -.07 & .14 & $.47 * * *$ & -.02 \\
\hline Punishing- Stern & .05 & $.40 * *$ & -.05 & $.55 * * *$ \\
\hline Remote-Quiet & $.35^{*}$ & .11 & -.24 & $.33^{*}$ \\
\hline Unchanging- Universal & -.04 & -.08 & $.27^{*}$ & -.21 \\
\hline
\end{tabular}

Note: $* * *$. Correlation is significant at the 0.001 level (2-tailed).

**. Correlation is significant at the 0.01 level (2-tailed).

*. Correlation is significant at the 0.05 level (2-tailed). 
God Concepts. 56

\section{Religious Coping}

I hypothesized (Hypothesis 3 ) that those individuals who viewed God as Punishing-Stern, Remote-Quiet, and less Loving-Kind would tend to adopt the selfdirective religious coping strategy. To examine this hypothesis, I began with an overall correlation of the God dimension and the religious coping subscales. In regards to the Punishing-Stern dimension, there was no significant relationship to the self-directive strategy. However, those participants who viewed God as Remote-Quiet and less LovingKind were more likely to use the self-directive coping strategy (see Table 6). A correlation within each group indicated that all four groups had a significant positive relation between Remote-God dimension and using the self-directive coping strategy. Loving-kind scores were significantly and negatively correlated with the self-directive coping style among Catholics and Protestants. Weaker negative correlations (not significant) were observed among Muslims and New Age/Spiritual participants.

I further hypothesized that those individuals who perceived God as PunishingStern would be more likely to adopt the deferring coping style. An overall correlation between the two factors indicated a significant positive correlation. However, the correlation between Punishing-Stern scores and deferential coping was only significant among Muslim and Protestant participants.

Finally, I hypothesized that a person perceiving God as Loving would also use the collaborative coping strategy. An overall correlation indicated a significant relation between Loving-Kind dimension and collaborative style. The within group correlations 
God Concepts. 57

indicated that in all four groups, those who viewed God as Loving also tended to use a collaborative coping style.

Table 6

Correlation of God Dimension with Religious Coping Variables.

\begin{tabular}{llll}
\hline & Collaborative & Deferring & Self-Directive \\
\hline Overall & & & \\
Loving-Kind & $.57^{* * *}$ & $.48^{* * *}$ & $-.46^{* * *}$ \\
Punishing- Stern & .06 & $.11^{* *}$ & -.004 \\
Remote-Quiet & $-.35^{* * *}$ & $-.23^{* * *}$ & $.41^{* * *}$ \\
Unchanging- Universal & $.44^{* * *}$ & $.35^{* * *}$ & $-.37^{* * *}$ \\
& & & \\
Catholic & & & \\
Loving-Kind & $.53^{* * *}$ & $.41^{* * *}$ & $-.38^{* * *}$ \\
Punishing- Stern & -.08 & -.04 & .04 \\
Remote-Quiet & $-.35^{* * *}$ & $-.23^{* * *}$ & $.31^{* * *}$ \\
Unchanging- Universal & $.29^{* * *}$ & $.17^{* *}$ & $-.26^{* * *}$ \\
& & & \\
Protestant & & & \\
Loving-Kind & $.61^{* *}$ & $.56^{* * *}$ & $-.58^{* * *}$ \\
Punishing- Stern & $.13^{11}$ & $.14^{*}$ & -.002 \\
Remote-Quiet & $-.46^{* * *}$ & $-.38^{* * *}$ & $.50^{* * *}$ \\
Unchanging- Universal & $.52^{* * *}$ & $.46^{* * *}$ & $-.46^{* * *}$ \\
& & & \\
Muslim & & $.32^{* *}$ & -.11 \\
Loving-Kind & $.51^{* * *}$ & $.29^{*}$ & .19 \\
Punishing- Stern & $.26^{*}$ & $.31^{* *}$ & $.42^{* * *}$ \\
Remote-Quiet & .07 & .23 & -.17 \\
Unchanging- Universal & $.44^{* * *}$ &
\end{tabular}

(Table 6 continues)

${ }^{11}$ For Protestants, when gender and age were partialled out of the correlation, the results for the Collaborative and Punishment-Stern dimension became significant $(r=.15, p<$ $.05)$ 
(Table 6 continued)

\begin{tabular}{llll}
\hline & Collaborative & Deferring & Self-Directive \\
\hline New Age/Spiritual & & & \\
Loving-Kind & $.42^{* *}$ & $.26^{* 12}$ & -.24 \\
Punishing- Stern & -.16 & -.08 & .16 \\
Remote-Quiet & $-.40^{* *}$ & $-.29^{* 13}$ & $.38^{* *}$ \\
Unchanging- Universal & $.36^{* *}$ & $.31^{*}$ & -.14 \\
\hline Note: ${ }^{* * *}$. Correlation is significant at the 0.001 level (2-tailed). \\
$\quad * *$. Correlation is significant at the 0.01 level (2-tailed). \\
$\quad$ *. Correlation is significant at the 0.05 level (2-tailed).
\end{tabular}

\section{Fundamentalism}

In my final hypothesis (4), I hypothesized that people who were fundamentalist in their theology would tend to have similar perceptions of God across faith groups, whereas those who were liberal in their theology would diverge in their perceptions of God. Since the instrument I used to measure liberalism was unsatisfactory, I can only assess whether people adopting fundamentalist beliefs have comparable views of God relative to those who do not hold fundamentalist beliefs. Before testing this hypothesis, I first compared the three religious groups (Protestants, Catholics and Muslims) and gender (males and females) on fundamentalism ${ }^{14}$. A 2 (Gender) by 3 (Group) ANOVA, indicated that the ${ }^{12}$ For New Age/Spiritual, when gender and age were partialled out of the correlation, the results for Deferring and Loving-Kind were no longer significant $(r=.20, n s)$.

${ }^{13}$ For New Age/Spiritual, when gender and age were partialled out of the correlation, the results for deferring and Remote-Quiet were no longer significant $(r=-.24, n s)$.

${ }^{14}$ As New Age/Spiritual participants do not have a unified, organised system of beliefs or a core religious doctrine or text, this group was excluded from the assessment of Footnote continued on next page. 
God Concepts. 59

main effect of gender is not significant $(F(1,570)=.15, n s)$ nor was the interaction of gender by religious group $(F(2,570)=.58, n s)$. As gender is not significant, I will focus on the main effect of religion which is significant $(F(2,570)=35.63, p<.001)$. The followed Scheffe post hoc tests indicate that Muslims tended to score higher on the fundamentalism measure $(M=4.25, S D=.68)$ than Catholics $(M=3.32, S D=.66)$ and Protestants $(M=3.67, S D=.99)(F(2,569)=42.53, p<.001)$.

I further examined whether age was related to fundamentalism. I conducted a correlation of age and fundamentalism and found there was no significant relation $(r=$ $.07, n s)$.

To test the hypothesis that fundamentalists within each faith group would be similar to fundamentalists in other faith groups, I first dichotomized fundamentalism at the mean for the combined sample, excluding New Age/Spiritual participants. ${ }^{15}$ I then conducted a 2 (fundamentalism) by 3 (faith group) MANOVA on the four God Concept scores.

Box's $M$ test for homogeneity of covariances indicated that the covariances were not homogeneous $(F(50,2698)=3.16, p<.001)$. To locate the source of the heterogeneity,

fundamentalism. The definition of fundamentalism used in my thesis is based on institutionalized religions and their primary holy text.

${ }^{15}$ Since Muslims tended to score higher on fundamentalism than Catholics and Protestants, they are somewhat under-represented in the low fundamentalism group ( $n=$ $6)$. 
God Concepts. 60

follow-up Box M tests were conducted separately for those scoring above the mean on fundamentalism and those scoring below the mean. The Box M test was not significant for those below the mean on fundamentalism $(M=38.94, F(20,593)=1.59, p=.05)$, but was significant for those scoring above the mean on fundamentalism $(M=81.50, F(20$, $187746)=3.99, p<.001)$. The heterogeneity of covariances among high fundamentalist groups suggests that the correlations among God concepts differ by religious group. Fundamentalist Muslims were the smallest group in these analyses $(n=67)$, but had the largest determinant. Protestants had the largest cell size $(n=112)$ and the smallest determinant. This suggests that F-tests will be liberal for analyses of group differences among fundamentalists.

Both main effects for fundamentalism and religious groups on the God Concept composite dependent variable were significant (Wilks' Lambda $=.95, F(4,563)=7.51, \mathrm{p}$ $<001$; and Wilks' Lambda $=.97, F(8,1126)=2.47, \mathrm{p}<.05$, respectively). Additionally, the interaction between fundamentalism and religious groups on the composite DV was also significant (Wilks' Lambda $=.96, F(8,1126)=3.143, \mathrm{p}<.01)$.

Given my hypothesis, I have focused on the interaction of religious group by fundamentalism. (The main effects of religious group have already been presented.) Since the multivariate interaction was significant, I examined the univariate interaction effects. These analyses indicated that the source of the multivariate interaction was attributable to a univariate interaction on the Punishing-Stern dimension $(F(2,564)=$ $6.23, \mathrm{p}<.01$ ). The interaction effects were not significant for the Loving-Kind dimension 
God Concepts. 61

$(F(2,564)=.03, n s)$, the Remote-Quiet dimension $(F(2,564)=1.28, n s)$, or the UniversalUnchanging dimension $(F(2,564)=.85, n s$.

To decompose the significant interaction on the Punishing-Stern dimension, simple effects were conducted such that the effect of religious group on Punishing-Stern scores was assessed among those scoring above the mean on fundamentalism (fundamentalist), and then for those scoring below the mean on fundamentalism (non-fundamentalists). For the fundamentalists, at least one religious group differed significantly from another on the Punishing-Stern $(F(2,566)=6.14, p<.01)$. Using the Tukey - Kramer procedure with a family wise alpha of .05 , the post hoc analysis comparison of religious groups indicated that fundamentalist Catholics $(M=2.09, S D=0.74)$ perceived God to be less punishingstern than the fundamentalist Muslims $(M=2.48, S D=0.86 ; 95 \% \mathrm{CI}$ of mean difference $=-.65,-.12)$. Fundamentalist Protestants $(\mathrm{M}=2.28, S D=0.64)$ perceived God to be marginally less punishing-stern than did fundamentalist Muslims (95\% CI of mean difference $=-.46, .06)$ and marginally more punishing-stern than did fundamentalist Catholics $(95 \% \mathrm{CI}$ of mean difference $=-.42, .05)$. See Figure 2 for visual depiction.

For the non-fundamentalists, at least one religious group differed significantly from another on the Punishing-Stern dimension $(F(2,566)=3.24, p<.05)$. The post hoc analysis using the Tukey-Kramer procedure with a family wise alpha of .05 , indicated that non-fundamentalist Catholics $(M=2.23, S D=0.71)$ perceived God to be marginally more punishing-stern than non-fundamentalist Protestants $(M=2.03, S D=0.63 ; 95 \%$ 
$\mathrm{CI}=.004, .41)$. Given the small number of non-fundamentalist Muslims $(n=6)$, no differences involving this group were significant $(M=1.86, S D=0.48)$.

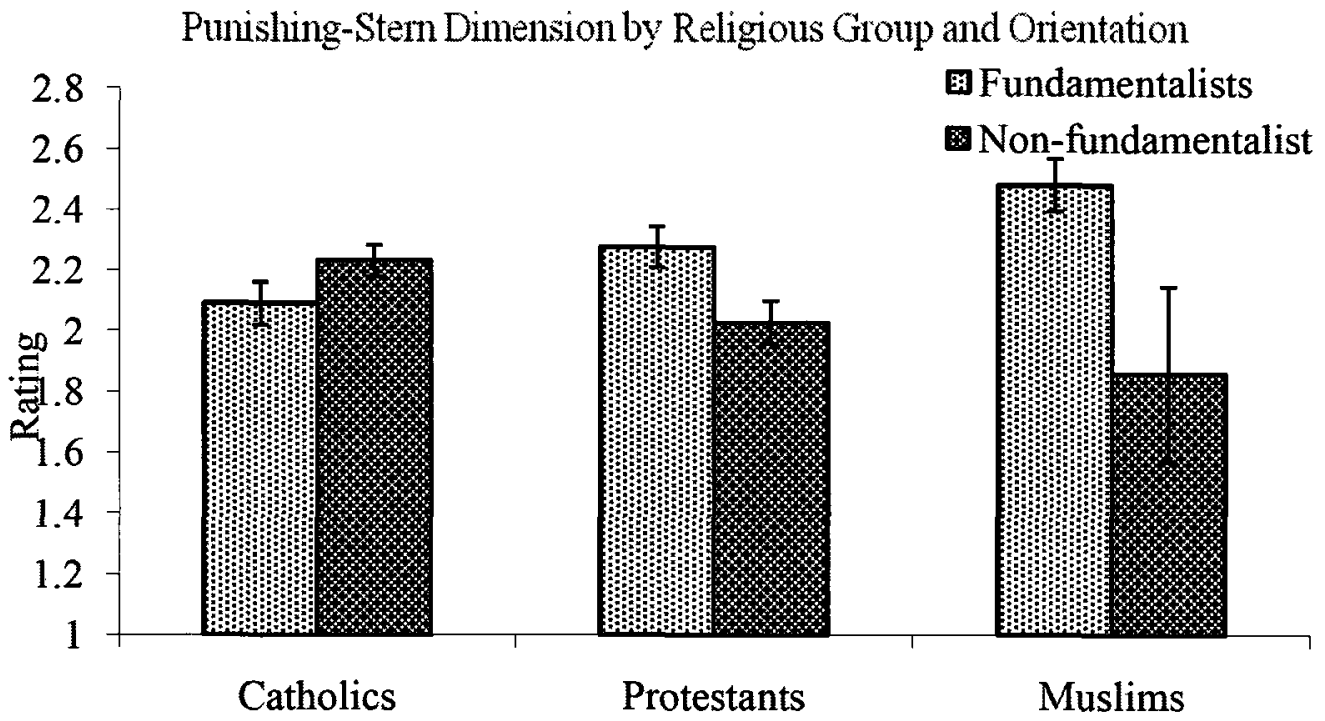

Figure 2. Mean (+/-SE) for Punishing-Stern God Concept score as a function of Faith Group and Fundamentalism. Sample sizes:

fundamentalist Catholics $(n=101)$, fundamentalist Protestants $(n=112)$, fundamentalist Muslims ( $n=67)$, non-fundamentalist Catholics $(n=$ 186), non-fundamentalist Protestants $(\mathrm{n}=100)$, and non-fundamentalist Muslims ( $(n=6)$.

\section{Religious Identity}

A oneway ANOVA, followed by Scheffe post hoc tests, indicated that Muslims tended to score significantly higher on the religious identity measure $(M=6.74, S D=$ 1.75) than Catholics $(M=4.53, S D=2.02)$, New Age/Spiritual $(M=4.89, S D=2.00)$ and Protestants $(M=4.92, S D=2.40)(F(3,631)=20.91, p<.001)$. See Figure 3 for visual representation. 


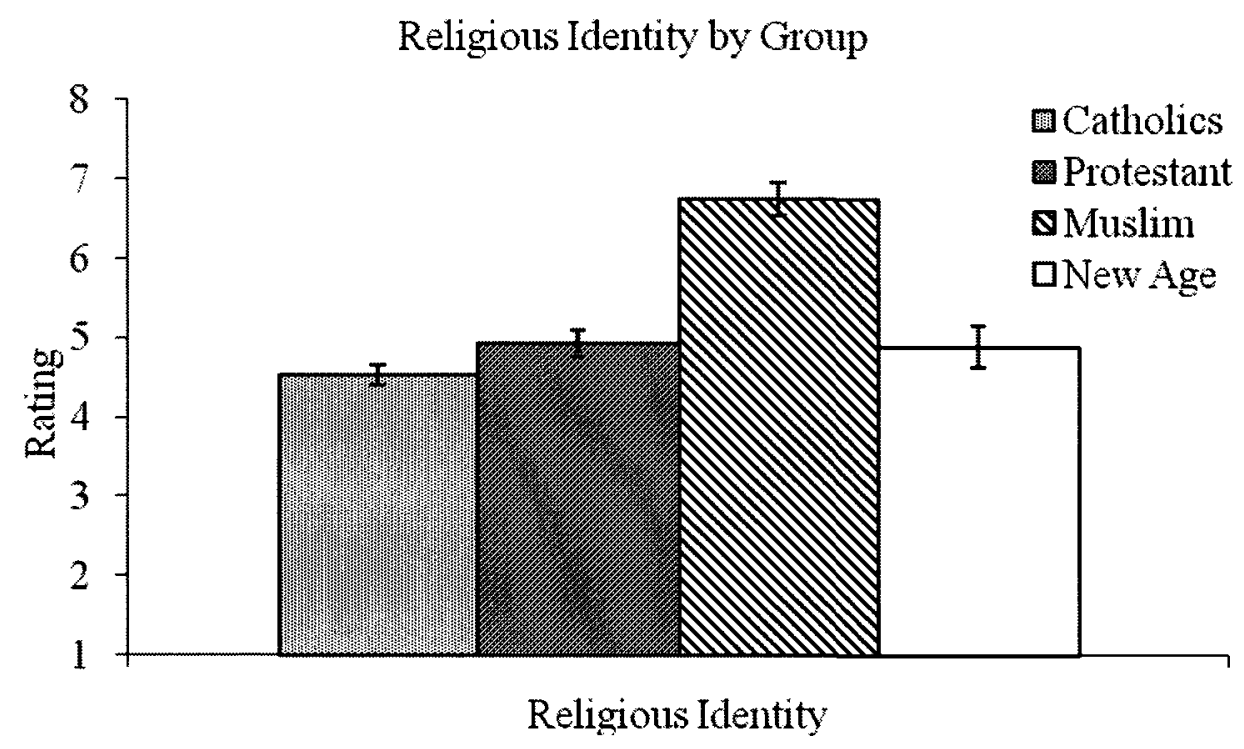

Figure 3. Mean Religious Identity scores for each group (+/-SE) for Catholics $(n=288)$, Protestants $(n=212)$, Muslims $(n=73)$, and New Age/Spiritual $(n=62)$.

To assess the extent to which religious identity was associated with God concept scores, I correlated religious identity scores with each of the God concept scores for the sample as a whole and within each faith group (see Table 7). Correlations were fairly consistent across the faith groups. In all groups, the more participants identified with their religious group, the more they perceived God to be loving and kind, and the more they perceived God to be unchanging and universal (although the coefficient falls just short of statistical significance for the New Age/Spiritual group). Among Catholics and Protestants, religious identity scores were significantly negatively correlated with perceiving God to be remote and quiet. The correlation of religious identity and 
God Concepts. 64

perceiving God as punishing and stern tended to be near zero for all groups except

Catholics, for whom a modest negative correlation $(r=-.17, p<.01)$ was observed.

These correlation coefficients did not change significantly when age and gender were controlled statistically. 
Table 7.

Correlation of God Dimension with Religious Identity.

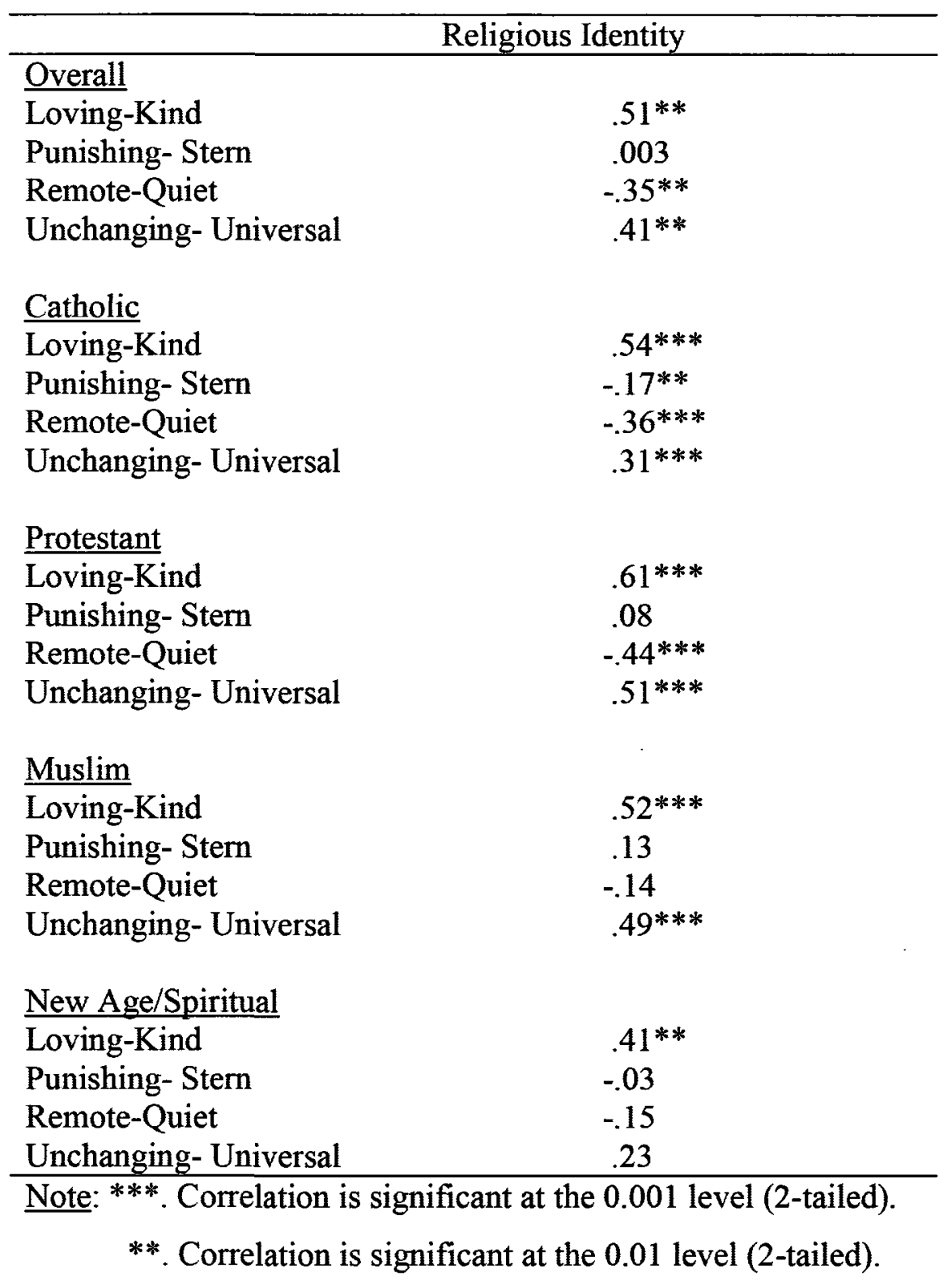


God Concepts. 66

\section{General Discussion}

The primary goal of this research was to examine God concepts from the perspective of people of different monotheistic faiths. The second goal was to explore how these perceptions of God relate to other psychological constructs such as assumptions of the world, locus of control, and religious coping strategies. Finally, I assessed whether people with more fundamentalist beliefs might be more similar to one another across faiths rather than people with more non-fundamentalist beliefs. In this discussion section, I will discuss the findings with respect to each of these goals.

\section{God Concepts}

Factor analyses suggested that each of the four faith groups (Christian-Catholic, Christian-Protestant, Muslim, and New Age/Spiritual) represented God in terms of the same four dimensions: Loving-Kind, Punishing-Stern, Remote-Quiet, and UnchangingUniversal. Although four dimensions are fewer than have been found in some other research (e.g., Benson and Spilka, 1973; Gorsuch, 1968), the dimensions I obtained have been found consistently by other investigators. For instance, the Loving-Kind and Punishing-Stern dimensions found in this research are very similar to the Loving and Controlling dimensions found by Benson and Spilka (1973), and the Caring and Wrathfulness dimensions found by Gorsuch (1968). The Remote-Quiet dimension is similar to Gorsuch's (1968) Deisticness factor as well as Benson and Spilka's (1973) Impersonal: Distant factor. Furthermore, the Unchanging-Universal is similar to 
Gorsuch's Eternality dimension, and Benson and Spilka's (1973) Impersonal: Allness factor.

Consistent with other research on Christian samples (e.g., Benson and Spilka, 1973, Hammersla Andrews-Qualls, \& Frease, 1986), I found modest negative correlations between the extent to which Christian participants thought of God as being Loving-Kind and the extent to which they thought of him as being Punishing-Stern. Interestingly, Muslim participants saw these two concepts as positively correlated. For the Muslim participants, God is both loving and punishing. The fact that Christians and Muslims perceive God differently is not surprising as both religions, while often using the same adjectives to describe God, emphasize different attributes. For example, whereas both religions teach that God is loving and merciful yet also capable of anger and punishment, Muslim teaching emphasizes that God is the Supreme Sovereign overseeing events from afar, capable of being both loving and punishing at the same time. Christians, on the other hand, are more likely to see God as either loving or punitive. Some Christians emphasize only the loving aspects of God, while others perceive God as more punitive. This distinction coincides with the perceived distinction between the God of the Old Testament and the God of the New Testament. As Bader and Froese (2005) points out, for some Christians, God is perceived as the God of the Old Testament, who is quick to anger and is active in the world, whereas other Christians perceive God as the God of the New Testament, who is perceived as loving, forgiving, and committed to his people. The tendency to see God as one way more than the other was observed among both 
God Concepts. 68

Protestants and Catholics, suggesting that this is not simply a difference between these two denominations.

Aside from the Loving-Kind and Stern-Punishing dimensions, the four religious groups also differed in the extent to which they saw God as unchanging-universal and remote-quiet, and in the extent to which these dimensions correlated with other dimensions. For example, although all groups associated a loving God with an unchanging God, and a remote God with a punishing God, Christians (Protestants and Catholics) who saw God as loving tended also to see God as near (i.e., not remote-quiet) whereas Muslims perceived no connection between these two dimensions. The Christian groups as well as the New Age/Spiritual participants perceived a punishing God as also being remote, which was separate from their perceptions of him being loving and universal. It is possible that for these two groups, only a distant God would be willing to punish, where a close God with intimate knowledge of the individual would more likely have compassion towards the individual rather than be punitive.

Relative to the other groups, New Age/Spiritual participants tended to see God as less loving, less punishing, and less unchanging/universal. This suggests that they see God in less anthropomorphic terms. For this group, God is not necessarily a deity like that of the monotheistic religions but rather as a spiritual dimension (Berg, 2008). In other words, the ineffable aspect of God is emphasized rather than his human-like qualities. With this in mind, the lower scores on the more anthropomorphic dimensions, Loving-Kind and Punishing-Stern is not surprising, as New Age believers tend to reject 
God Concepts. 69

institutionalized religions' understanding of God (Hanegraaff, 1998). Unlike Christians who emphasize a personal God, or Muslims who emphasize a Supreme Sovereign, New Age/Spiritual individuals are more likely to comprehend God as a quiet energy that encompasses the entire universe.

Muslims, relative to the other groups, tended to score God high on the loving and unchanging dimensions, and although not significantly so, higher on the punishing dimension as well. This tendency to ascribe more of everything to God is reminiscent of the 99 names of Allah, compiled from various Qur'an verses, in which God is ascribed characteristics that do not seem consistent (at least from a secular perspective). For instance, among the 99 names ascribed to Allah are Al-Mujeeb (The Responsive), AlBaatin (The Hidden), Al-Muthil (The Humiliator), and Ash-Shakoor (The Grateful; see Appendix I for the full list).

It is important to note that mean differences do not take into account differences in the extent to which people actually believe in God. It is not clear whether participants were rating the extent to which they felt that God should have the various characteristics or the extent to which they felt that God actually possessed these characteristics. The finding that Muslims tended to score God higher on most items might reflect a greater confidence (or a greater faith) in what God is like relative to other groups. Although I might have been able to control for this somewhat had I assessed religiosity, it should be noted that norms and expectations differ greatly across religions on items that are typically used to assess religiosity (e.g., frequency of prayer, frequency of attendance at 
God Concepts. 70

services, frequency with which the holy text is read). Therefore, the use of a standard measure of religiosity would not have been sufficient to account for differences between groups in the extent to which they believe that God actually possesses the ascribed characteristics.

Though all four groups indicated a similar understanding of God, it is clear that the attributes they emphasize differ. These emphasized differences were often echoed in relation to the psychological constructs that were included in this study and will presently be discussed.

\section{God Concepts and the Assumptive World}

In this section, I explored how a person's conceptualization of God is related to his or her assumptions of the world. Working from the premise that differences in one's conception of God have implications for how one relates to the world at large, I assessed the extent to which participants' God concepts correlated with distinct world assumptions. In general, I found weak to modest correlations between God concepts and world assumptions, although the magnitude and direction of correlations varied by religious group. For instance, I found support for the hypothesis that those who saw God as more punitive would also see the world as more meaningful - but only among Catholics, Muslims, and New Age/Spirituals. For Catholics and Muslims, this finding makes sense: their theologies support that notion that God punishes sinful acts (thus perhaps leading to the belief that the world is just and ordered). It is, however, surprising 
God Concepts. 71

that New Age/Spirituals would show this link, as they tend not see God as punishing or stern.

I had predicted that those who saw God as more punishing-stern would also tend to see the external world as less benevolent. The analyses did not support this hypothesis. Indeed, among Muslims, perceptions of God as stern and punishing were (positively) associated with perceiving the world as more benevolent. Although perceptions of God as being more punishing-stern were not, in general, associated with perceiving the world as less benevolent, those who perceived God to be more loving and kind tended also to see the world as more benevolent.

I had also hypothesized that people who perceive God as loving would also report greater self-worth. Surprisingly, the data did not support this hypothesis. As the Worthiness dimension of the World Assumption Scale includes degrees of one's selfesteem, this finding is contrary to Benson and Spilka's (1973) findings that self-esteem was related to a loving God image and negatively related to "rejecting-impersonal and controlling" God image. In the present study, the more Catholics and Muslims perceived God as punishing-stern, the higher their self-worth. Perhaps knowing that God punishes misbehaviour keeps one acting in accord with God's wishes, and believing that one is living up to God's expectations may confer a sense of self-worth.

\section{God Concepts and Loci of Control}

In a further attempt to link God concepts to other psychological constructs, I correlated participants' scores on the four God concept dimensions to the God Locus of 
God Concepts. 72

Control dimension. I had anticipated that God control on the revised Locus of Control scale would correlate positively and significantly with the extent to which participants felt God was loving, I found support that the more people perceive God to be in control of outcomes, the more they perceive God to be loving and kind. These correlations were quite strong for all four faith groups.

\section{God Concepts and Religious Coping}

It was expected that the endorsement of participants' God concepts would be significantly correlated to the three religious coping styles as previous research had indicated (McDonald-Wong \& Gorsuch, 2004; Maynard, Gorsuch, \& Bjorck, 2001). The study demonstrates that participants from all four groups who perceived that God is loving were more likely to indicate that they seek God's guidance as they cope with difficult situations. Scores on the loving - kind dimension correlated substantially and positively with both the collaborative coping style and the deferring coping style. This study has also shown that for all the groups the more distant they perceived God, the more they excluded him from the problem solving process. This result supports Maynard, Gorsuch and Bjorck's findings (2001) that for those participants who were more likely to use the self-directive coping strategy, they perceived God as distant or removed. These findings suggest that one's understanding of God is closely connected to the way that one responds to stress, at least among people of faith. It is interesting that these correlations were observed in each of the faith groups. While it may be the case that some faith groups may emphasize more than others the importance of taking one's problems to God, 
God Concepts. 73

even within faith groups, some individuals are more likely than others to do so.

Irrespective of one's religion, whether or not one involves God in coping issues seems to be tied to what images come to mind as one thinks of God.

\section{God Concepts and Fundamentalism}

In recent years, fundamentalist religions have undergone "unprecedented global growth" (Myers, 2004, p 60) and have captured the interest of political scientists, sociologists and historians. Yet despite this growing awareness, psychologists have done little research into this phenomenon (Hood, Hill, \& Williamson, 2005). With this in mind, I endeavoured to expand our current understanding of both non-fundamentalist and fundamentalist orientation by considering the extent to which fundamentalism relates to perceptions of God. I had hypothesized that fundamentalists of different faiths would be more similar to one another than they would be to those who were liberal. Although my measure of liberalism was problematic, I found no support for the hypothesis that fundamentalists of different faiths would be more similar than those who were not fundamentalist in their ideology. First, there was more (not less) variability in perceptions of God among fundamentalists (relative to those who were not fundamentalist). Second, the interaction of fundamentalism by religious group suggested greater between faith group differences among fundamentalists than among those who were not fundamentalists. Among fundamentalists, religious groups differed with respect to the perception of God's punitiveness such that Catholic fundamentalists tended to see God as less punitive than did Muslim fundamentalists (with Protestant fundamentalists seeing 
God Concepts. 74

God as part way between the other two groups). The trend appeared to be going in the other direction among non-fundamentalists, although the cell size for Muslims was too small to yield significant differences for this group. My hypothesis did not fully take into account the significant differences in God concepts that each religion would emphasize. Furthermore, I did not take into account the full ramifications of the definition of fundamentalism set forth in this document. For example, fundamentalist Muslims follow the traditions and rituals of their faith. As such, they follow the teachings of the Qur'an, and perceive God as a Supreme Sovereign, a distant ruler watching over his subjects, in whom Muslims must completely submit. Fundamentalist Christians, on the other hand, have their own unique traditions, follow the teachings of the Bible, and tend to believe in a personal parental God, whether he be a personal authoritarian parent or a personal authoritative parent. In this light, it is understandable that the two fundamentalist groups were heterogeneous in their conceptualization of God.

\section{God Concepts and Religious Identity}

Religious identity is considered to be an aspect of social identity (Abu-Rayya \& Abu-Rayya, 2009). Social identity as well as religious identity has been defined as the part of an individual's self-concept which derive from his or her awareness of membership in a social or religious group, and includes the value and emotional significance of being a member of the group (Abu-Rayya \& Abu-Rayya, 2009). Examination of the four religious groups' means on religious identity indicates that the Muslim participants scored significantly higher on religious identity than did Catholic, 
God Concepts. 75

Protestant and New Age/Spiritual participants. This suggests that Muslims identify more with other Muslims. This is similar to the findings of Keyes and Reitzes (2007), in which they found that religious identity was more important to Muslim participants than it was with Christians. Differences found in the current study may be understood by viewing religion as a culture. Islam is considered to be a collective religious culture (Richardson, 2004) in comparison to Protestant Christianity, which is considered an individualistic religion (Cohen \& Hill, 2007). At the core of collectivism is "the assumption that groups bind and mutually obligate individuals" (Oyserman, Coon, \& Kemmerlmeier, 2002, p. 5). For many collectivist religious cultures, social connections are an integral aspect of a person's life, and group affiliation is not only seen as important, but may be considered a defining aspect of identity (Cohn \& Hill, 2007).

Religious identity was then examined in relation to individual's God concepts. Consistent across all four groups was the relationship between an individual's religious identity and perceiving God as unchanging and loving. The more an individual perceived God as loving and constant, the more he or she identified with his or her religious group. It is possible that a loving and unchanging God is part of the cohesiveness that binds a group together. Group cohesiveness is the force that helps connect members of a group more closely to one another (Beal, Cohen, Burke, \& McLendon, 2003). One dimension of group cohesion is the emotional aspect (Beal et al., 2003). It is being speculated that belief in a loving and unchanging God has a positive emotional impact upon the believer and that this emotional connection may be transferred to others from the same religious 
God Concepts. 76

group, who are assumed to have the same perception of God, thereby increasing one's connection with the religious group.

\section{Implications for Future Research}

This research has extended our understanding of God concepts beyond the Christian religion. The exploration of the four faith groups - Catholic, Protestant, Muslim and New Age/Spiritual - has shown that the groups do not conceptualize God identically. This suggests that one should not generalize perceptions of God from Christian samples to non-Christian faith groups. Although Catholics and Protestants have similar views of God, these groups tend to differ significantly from Muslims and New Age/Spirituals both in terms of the extent to which God is perceived to possess various characteristics and in the extent to which these God concepts relate to one another and to other psychological constructs. This research represents a first step in understanding the role that God concepts play in the lives of Catholics, Protestants, Muslims, and New Age/Spirituals. Future research is needed to assess the extent to which these God concepts remain stable over time, whether and how they are affected by life experiences and exposure to people of other faiths. Although there was not much evidence of people changing faiths, it is probably the case that for many people, faith in God and understanding of God changes over time. For instance, people who experience a trauma or loss often report that their perceptions of God have changed (Cheston, Piedmont, Eanes, \& Patrice Lavin, 2003; Doehring, 1993; Pargament, 2007). It would be interesting to assess with pre and post measures the extent to which the four dimensions of God identified in this study change 
as a result of such experiences. People might, for instance, see God as more punitive, more remote, or less loving in the immediate aftermath, but then gradually change these perception to a more differentiated view of God over time (e.g., he gives and he takes away; he tests us and he rewards us).

Perhaps the most significant theoretical implication of these findings is that one's view of God might have a bearing on how one perceives the world and events that happen, and how one attempts to cope. People differ in their perception of God, and these different perceptions of God are associated with a variety of assumptions, ways of perceiving, and coping styles. To the extent that these assumptions and perceptions affect behaviour, one might also anticipate that differences in perceptions of God might also lead to different response tendencies. Different perceptions of God might affect a range of attitudes and behaviours ranging from willingness to forgive and engage in prosocial behaviour to one's willingness to cheat, lie, and deceive.

Future research in psychology of religion should also endeavour to include New Age participants. Much of the research done in psychology of religion has neglected the New Age/Spiritual practitioners because this group does not easily correspond to what measures of religiosity are examining, such as church attendance or reading of devotions (Greer \& Roof, 1992). As this study has shown, personal religious variables (such as a person's ideas of what God is like) are correlated with other areas of life experience, even for New Age/Spiritual followers. Not to include New Age/Spiritual followers in research on the psychology of religion is, I believe, a great oversight. 
God Concepts. 78

As this study was primarily one of exploration of four religious/spiritual groups, more in-depth and wider range of religions need to be studied. As Christianity has been the main focus of much research, inclusion of the other major religions (such as Hinduism, Judaism, and Islam) would further extend our understanding of God concepts and their relations to other psychological constructs.

\section{Limitations of Study}

Though this study was limited to four different religious groups for analysis sake, the initial 1161 participants were from a wide range of religious backgrounds such as Baha'i, Buddhist, Hindu, Jewish, and others. However, because some of these groups were represented by a very small number of people, I was forced to focus only on those who identified themselves as Protestant, Catholic, Muslim or New Age/Spiritual. The lack of participants from these other religions is a significant limitation of the study.

A second limitation of this study is that the samples of Catholics, Protestants, Muslims and New Age/Spirituals may not be representative of their respective religious groups. For example, the majority of Muslim participants were likely immigrants (or second generation) to Canada, a predominantly Christian country. There is no way of knowing whether the Muslim sample is representative of Muslims in general, or even representative of Muslims living in Canada as a religious and ethnic minority. My data do not allow me to determine the extent to which Muslim participants were defining themselves solely in relation to their religion, or relative to the Christian majority. When Muslim participants were asked about Allah, they may not have only reflected on their 
God Concepts. 79

own religious and personal experiences or beliefs, but may have also incorporated as a reference point how Allah is different from (what they understand as) the Christian God (e.g., relative to the Christian God, Allah is a lot more stern, punishing, loving, etc). One possible solution for this problem would be to have this study replicated in other cultures, for example in an Islamic country, where Christians are the minority group.

All participants were required to complete this survey from locations other than the lab, and therefore no direct contact with the researcher was made. This allowed the participants to complete the survey at their leisure and without any influence from the researcher. Furthermore, of the 1161 participants, $12 \%$ of the respondents were not from the university student population. Therefore, the results of this study reaches beyond the typical studies that are often limited to the local cities and student populations where the study originated. A limitation of this method is that the participants were not able to clarify items with the researcher.

Future studies might also include other religiosity or spirituality measures, such as asking how frequently participants attend spiritual/religious gatherings (i.e., church, mosque, or spiritual retreats), or how often they pray or meditate, how often do they read about their religion or spiritual belief, and what are their religious/spiritual motivation. The Benson and Spilka (1973) study correlated God concepts with self esteem, partialling out religious activities, such as prayer and church attendance, and found that the God concepts were still significantly related to self esteem. However, this is the only study that I am aware of the controlled for religious activities. 
God Concepts. 80

\section{Conclusion}

In summary, this thesis has shown how God concepts vary between religious and spiritual groups, and how these God concepts relate to one's world assumptions, locus of control, religious coping and religious identity. Although Catholic and Protestant Christians are quite similar in how they view God, and show similar relations between these God concepts and world assumptions, locus of control, coping, and religious identity, they differ significantly from Muslims and those who are New Age/Spiritual. It is clear that while members of religious groups use similar terms to describe God, the emphasis each group places on these terms make them different from each other.

These glimpses into the four faith groups' perceptions of God have shown that as researchers, we should not assume that people of faith share a common understanding of God. This exploration of the four groups God concept has led me to a deeper appreciation for how each group's unique perception contributes to the study of Psychology of Religion.

Our experiences are filled with assumptions we hold regarding the world, and for religious and/or spiritual individuals, these assumptions are seen through the lens of their individual perceptions of God. This study has shown that within each faith group, concepts of God play an intricate part in the assumptions held about events in other people's lives, the material world, or events in the personal life of participants. This study also suggests that God concepts relate to perceptions of 
God Concepts. 81

control and how one copes with life's slings and arrows. People who perceive God as kind, loving and compassionate are more likely to seek God's help in solving daily problems than those who do not view God as possessing these characteristics. People who consider God to be distant and passive are more likely to exclude God from their coping efforts.

At the heart of this thesis are the individual conceptualizations of God held by people of different faiths. I have argued that these conceptualizations of God are important to understand because, for people of faith, they influence how one relates to and understands the world, how one deals with other people, and how one handles stressful experiences. Psychology of Religion has shown a keen interest in how people deal with life events, yet most of this research has neglected to recognize the specific and unique role that different perceptions of God might have on these other issues and processes. Much of the psychology of religion has focused on religious activities rather than the force behind these activities -- God. This thesis has shown that for religious and/or spiritual individuals, the concept of God relates to one's experience of life on multiple levels. 
God Concepts. 82

\section{References}

Abu-Rayya, M. H., \& Abu-Rayya H. M. (2009). Ethnic identification, religious identity, and psychological well-being among Muslim and Christian Palestinians in Israel. Mental Health, Religion \& Culture, 12, 147-155.

Bader, C., Froese, P. (2005). Images of God: The effect of personal theologies on moral attitudes, political affiliation, and religious behavior. Retrieved on November 27, 2005 from Interdisciplinary Journal of Research of Religion, www.religjournal.com, 1, article 11 .

Beal, D. J., Cohen, R. R., Burke, M. J., \& McLendon, C. L. (2003). Cohesion and performance in groups: A meta-analytic clarification of construct relations. Journal of Applied Psychology, 88, 989-1004.

Bednarowski, M. F. (1995). New Religions and the Theological Imagination in American. Bloomington, IN: Indiana University Press.

Benson, P. \& Spilka, B. (1973). God image as a function of self-esteem and locus control. Journal for the Scientific Study of Religion, 12, 297-310.

Berg, M. C. (2008). New age advice: ticket to happiness? Journal of Happiness Studies, $9,361-377$.

Bibby, R. W. (2001). Canada's Teens: Today, Yesterday, and Tomorrow. Toronto: Stoddart Publishing Co. Ltd.

Bibby, R. W. (2002). Restless gods: The renaissance of religion in Canada. Toronto: Stoddart Publishing Co. Ltd. 
God Concepts. 83

Boivin, M. J., Darling, H. W., \& Darling, T. W. (1987). Racial Prejudice Among Christian and Non-Christian College Students. Journal of Psychology and Theology, 15, 47-46.

Breault, K. D. (1989). New evidence on religious pluralism, urbanism, and religious participation. American Sociological Review, 54, 1048-1053.

Buri, J. R., \& Mueller, R. A. (1993). Psychoanalytic theory and loving God concepts: Parent referencing versus self-referencing. The Journal of Psychology, 127, 1727.

Cavey, B. (2007). The End of Religion. Colorado Springs, CO: NavPress.

Chandramohan, S. (2007). Sacred Elements of Hinduism. Retrieved on August 27, 2009 from Article Base, www.articlesbase.com/religion-articles/sacred-elements-ofhinduism-290388.html.

Cheston, S. E., Piedmont, R. L., Eanes, B., \& Patrice Lavin, L. (2003). Changes in clients' images of God over the course of outpatient therapy. Counseling and Values, 47, 96-108.

Ciaravino, H. (2001). Islam, Allah and prayer. Retrieved from Muslim Gateway on June 18, 2009. www.muslimgateway.com.

Cohen, A. B., \& Hill, P. C. (2007). Religion as culture: Religious individualism and collectivism among American Catholics, Jews, and Protestants. Journal of Personality, 75, 709-742. 
God Concepts. 84

Degelman, D., \& Lynn, D. (1995). The development and preliminary validation of the Belief in Divine Intervention Scale. Journal of Psychology and Theology, 23, $37-$ 44.

Dickie, J. R., Ajega, L. V., Kobylak, J. R. \& Nixon, K. M. (2006). Mother, father, and self: Sources of young adults' God concepts. Journal for the Scientific Study of Religion, 45, 57-71.

Doehring, C (1993). Internal Desecration: Traumatization and Representations of God. Lanham, MD: University Press of America.

Driscoll, M. (2008). On the Old Testament. Wheaton, IL: Crossway Books.

Dwairy, M. (2006). Counseling and Psychotherapy with Arabs and Muslims: A Culturally Sensitive Approach. New York: Teachers College Press.

Emerson, M. O, \& Hartman, D. (2006). The rise of religious fundamentalism. Annual Review of Sociology, 32, 27-44.

Ferguson, R. (2007, July 23). Didn't that sins-of-the-fathers stuff go out with the ark? The Herald - Glasgow (UK). (Features Section, para. 5).

Fidell, L. S. \& Tabachnick, B. G. (2007). Using multivariate statistics, Fifth Ed. Boston: Pearson.

Folkman, S. \& Lazarus, R. S. (1984). Stress, appraisal, and coping. New York: Springer Publishing Co.

Furnham, A. F. (1982). Locus of control and theological beliefs. Journal of Psychology and Theology, 10, 130-136. 
God Concepts. 85

Gallup Poll Monthly. (2007, May 10-13). Belief in God.

Geist, C., \& Bangham, W. (1980). Locus of control and religious affiliation. Psychological Reports, 47, 1281-1282.

Gorsuch, R. L. (1967). Dimensions of the conceptualization of God. International Yearbook for the Sociology of Religion, Sociology of Religion: Theoretical Perspectives, 2, 187-199.

Gorsuch, R. L. (1968). The conceptualization of God as seen in adjectives ratings. Journal for the Scientific Study of Religion, 7, 56-64.

Granqvist, P., Ivarsson, T., Broberg, A. G., \& Hagekull, B. (2007). Examining relations among attachment, religiosity, and New Age spirituality using the adult attachment interview. Developmental Psychology, 43, 590-601.

Greer, B. A., \& Roof, W. C. (1992). "Desperately seeking Sheila": Locating religious privatism in American society. Journal for the Scientific Study of Religion, 31, 346-352.

Groothuis, D. (2006). Unmasking the New Age. Westmont, IL: Intervarsity Press.

Hammersla, J. F., Andrews-Qualls, L. C., \& Frease, L.G. (1986). God concepts and religious commitment among Christian university students. Journal for the Scientific Study of Religion, 25, 424-435.

Hanegraaff, W. J. (1998). New Age Religion and Western Culture. Albany, NY: State University of New York Press. 
Harris, H. N., \& Valentiner, D. P. (2002). World assumptions, sexual assault, depression, and fearful attitudes toward relationships. Journal of Interpersonal Violence, 17, 286-305.

Harrison, M. O., Koenig, H. G., Hays, J. C., Eme-Akwari, A. G., \& Pargament, K. I. (2001). The epidemiology of religious coping: A review of recent literature. International Review of Psychiatry, 13, 86-93.

Hill, P. C., Pargament, K. I., Hood, Jr. R. W., McCullough, M. E., Swyers, J. P., Larson, D. B., \& Zinnbauer, B. J. (2000). Conceptualizing religion and spirituality: Points of commonality, points of departure. Journal for the Theory of Social Behaviour, 30 , $51-77$.

Hood, R. W., Hill, P. C., \& Williamson, W. P. (2005). The Psychology of Religious Fundamentalism. New York: Guilford Press.

Hurricane Katrina Destroys New Orleans Days before "Southern Decadence" 8/31/05. Retrieved from the world wide be on February 22, 2008, from http://www.repentamerica.com/pr_hurricanekatrina.html

Ipsos-Reid (April 2000). Canada - A Nation of Believers. Retrieved on August 30, 2007 from www.ipsos-na.com/news/pressrelease.cfm?id=1019.

Islahi, A. A. (2006). People's relationship with Allâh. Retrieved from Islam Online Net on June 18.2009. www.islamonline.net/servlet

Janoff-Bulman, R. (1989). Assumptive worlds and the stress of traumatic events: Applications of the schema construct. Social Cognition, 7, 113-136. 
God Concepts. 87

Jeavons, S. \& Greenwood, K. M. (2007). World assumptions, coping and attributions. Personality and Individual Differences, 42, 1427-1437.

Johnson, C. (2009, April 29). God in the Old Testament and New Testament. Retrieved from Public Service Project, on August 25, 2009, mbsoft.com/public/godotno.html.

Keyes, C. L. M., \& Reitzes, D. C. (2007). The role of religious identity in the mental health of older working and retired adults. Aging \& Mental Health, 11, 434-443.

Kirkpatrick, L. A. \& Shaver, P. R. (1990). Attachment theory and religion: Childhood attachment, religious beliefs, and conversion. Journal or the Scientific Study of Religion 29:315-34.

Koenig, H. G. (1998). Handbook of Religion and Mental Health. San Diego, Ca: Academic Press.

Koenig, H. G., McCullough, M. E., \& Larson, D. B. (2001). Handbook of Religion and Health. NY: Oxford University Press.

Lach, J. (1966), Two Concepts of God. The Harvard Theological Review, 59, 227-240.

Lawrence, R. T. (1997). Measuring the image of God: The God image inventory and the God image scales. Journal of Psychology and Theology, 25, 214-226.

Lerner, M. (2000). Just world belief. In A. E Kazdin, (Ed.) Encyclopaedia of Psychology, Vol. 4., 425-427. Washington, DC: American Psychological Association.

Levenson, H. (1973). Multidimensional locus of control in psychiatric patients. Journal of Consulting and Clinical Psychology, 41, 397-404. 
God Concepts. 88

Marsden, G. (1990). Defining American fundamentalism. In N. J. Cohen (Ed.), The Fundamentalist Phenomenon, 22-37. Grand Rapids, MI: William B. Eerdmans Publishing Company.

Martin, D. (1990). Fundamentalism: An observational and definitional Tour D'Horizon. The Political Quarterly, 61, 129-131.

Maynard, E. A., Gorsuch, R. L., \& Bjorck, J. P. (2001). Religious coping style, concept of God, and personal religious variables in threat, loss, and challenge situations. Journal for the Scientific Study of Religion, 40, 65-74.

McIntosh, D. N., Kojetin, B. A., \& Spilka, B. (1985). Form of personal faith and general and specific locus of control. Presented at the 1985 Convention of the Rocky Mountain Psychological Association, Tucson, Arizona.

Myers, G. E. (2004). Merging the horizons of psychotherapeutic and religious worldviews: New challenges for psychotherapy in the global age. Mental Health, Religion \& Culture, 7, 59-77.

Noffke, J. L. \& McFadden, S. H. (2001). Denominational and age comparisons of god concepts. Journal for the Scientific Study of Religion, 40, 747-756.

Odebode, M. (2007, February 30). The concept of God in Christianity, Islam and African traditional religion and their interaction in West Africa: A comparative approach. Journal for the Renewal of Religion and Theology. Retrieved on August 27, 2009 from http://www.renewtheology.org/paperMorounOdebode1007.htm. 
Osgood, C. E., Suci, G. J., \& Tannenbuam, P. H. (1957). Measurement of Meaning. Urbana, Ml.: University of Illinois Press.

Owen, S. D., O'Grady, K. A., Smith, T. B. \& Richards, P. S. (2005). Theistic perceptions of God. Paper presented at the 2005 annual convention of the American Psychological Association.

Oyserman, D., Coon, H. M., \& Kemmerlmeier, M. (2002). Rethinking individualism and collectivism: Evaluation of theoretical assumptions and Meta-Analyses. Psychological Bulletin, 128, 3-72.

Pargament, K. I. (1997). The Psychology of Religion and Coping: Theory, Research, Practice. New York: Guilford Press.

Pargament, K. I. (2007). Spiritual Integrated Psychotherapy: Understanding and Addressing the Sacred. New York: Guilford Press.

Pargament, K. I., Kennell, J., Hathaway, W., Grevengoed, N., Newman, J., and Jones, W. (1988). Religion and the problem-solving process: Three styles of coping. Journal for the Scientific Study of Religion, 27, 90-104.

Pargament, K. I., Tyler, F. \& Steele, R. (1979). The church/synagogue and the psychosocial competence of the member: An initial inquiry into a neglected dimension. American Journal of Community Psychology, 7, 649 - 664.

Pinnock, C. H. (1990). Defining American fundamentalism: A response. In N. J. Cohen (Ed), The Fundamentalist Phenomenon (38-55). Grand Rapids, MI: William B. Eerdmans Publishing Company. 
God Concepts. 90

Pollner, M. (1989). Divine relations, social relations, and well-being. Journal of Health and Social Behavior, 30, 92-104.

Redden, G. (2002). The new agents. Journal of Consumer Culture, 2, 33-52.

Richards, D. G. (1991). The phenomenology and psychological correlates of verbal prayer. Journal of Psychology and Theology, 19, 354-363.

Richardson, P. M. (2004). Possible influences of Arabic-Islamic culture on the reflective practices proposed for an education degree at the Higher Colleges of Technology in the United Arab Emirates. International Journal of Educational Development, $24,429-436$.

Ritzema, R. (1979). Attribution to supernatural causation: An important component of religious commitment? Journal of Psychology and Theology, 7, 286-293.

Robertson, B. A. (2006). Christian Faith Groups: From Amish to the Way. Retrieved from Religious Tolerance Organization, http://www.religioustolerance.org/chr_cf.htm, on January 18, 2008.

Rotter, J. B. (1966). Generalized expectancies for internal versus external control of reinforcement. Psychological Monographs, 80, whole issue.

Samat, T. (2003). The 99 most eminent names of Allah. Utusan Publications \& Distributors Sdn Bhd: Kuala Lumpur.

Schaefer, C. A., \& Gorsuch, R. L. (1991). Psychological adjustment and religiousness: the multivariate belief-motivation theory of religiousness. Journal for the Scientific Study of Religion, 30, 448-461. 
God Concepts. 91

Scharfstein, B. (1993). Ineffability. New York: State University of New York Press.

Spilka, B., Armatas, P., \& Nussbaum, J. (1964). The concept of God: A factor analytic approach. Review of Religion Research, 6, 28-36.

Stellway, R. I., (1973). The correspondence between religious orientation and sociopolitical liberalism and conservatism. Sociological Quarterly, 14, 430-439.

The Holy Qur $\square$ ân: Arabic Text and English Translation Explained by Nooruddîn A. R. Omar \& A. M. Omar, Trans.) Hockessin, DE: Noor Foundation International Inc.

Thurston, N. S. (1999). Religious problem-solving scale. In P. C. Hill and R. W. Hood, Jr. (Eds.) Measure of Religiosity, Birmingham, Al.: Religious Education Press.

Ward, K. (1998). Concepts of God: Images of the Divine in Five Religious Traditions. Oxford: Oneworld Publications.

Welton, G. L. (1999). Multidimensional Locus of Control Scales, in P. C. Hill and R. W. Hood, Jr. (Eds.) Measure of Religiosity, Birmingham, Al.: Religious Education Press.

Welton, G. L., Adkins, A. G., Ingle, S. L., \&. Dixon, W. A. (1996). God control: The fourth dimension. Journal of Psychology and Theology, 24, 13-25.

Wong-McDonald, A., \& Gorsuch, R. L. (2004). A multivariate theory of God concept, religious motivation, locus of control, coping, and spiritual well-being. Journal of Psychology and Theology, 32, 318-334. 


\section{Appendix A: God Concept Survey}

We are interested in understanding the different ways in which people think about what God/Allâh/Higher Power is like. Please rate the extent to which you think each of the items below describes God/Allâh/Higher Power by placing a check mark $(\checkmark)$ on the appropriate box. For instance, if you agree with the descriptor "God/Allâh/Higher/Sacred is ALWAYS like this", place the check mark on the furthest to the right box.

\begin{tabular}{|l|c|c|c|c|c|}
\cline { 2 - 6 } \multicolumn{1}{l|}{} & $\begin{array}{c}\text { God is } \\
\text { NEVER like } \\
\text { this. }\end{array}$ & $\begin{array}{c}\text { God is } \\
\text { RAREY like } \\
\text { this }\end{array}$ & $\begin{array}{c}\text { God is } \\
\text { SOMETMES } \\
\text { like this }\end{array}$ & $\begin{array}{c}\text { God is } \\
\text { OFTEN like } \\
\text { this }\end{array}$ & $\begin{array}{c}\text { God is } \\
\text { ALWAYS like } \\
\text { this }\end{array}$ \\
\hline Aloof & $\square$ & $\square$ & $\square$ & $\square$ & $\square$ \\
\hline Angry & $\square$ & $\square$ & $\square$ & $\square$ & $\square$ \\
\hline Charitable & $\square$ & $\square$ & $\square$ & $\square$ & $\square$ \\
\hline Close & $\square$ & $\square$ & $\square$ & $\square$ & $\square$ \\
\hline Cold & $\square$ & $\square$ & $\square$ & $\square$ & $\square$ \\
\hline Comforting & $\square$ & $\square$ & $\square$ & $\square$ & $\square$ \\
\hline Compassionate & $\square$ & $\square$ & $\square$ & $\square$ & $\square$ \\
\hline Constant & $\square$ & $\square$ & $\square$ & $\square$ & $\square$ \\
\hline Controlling & $\square$ & $\square$ & $\square$ & $\square$ & $\square$ \\
\hline Convenient & $\square$ & $\square$ & $\square$ & $\square$ & $\square$ \\
\hline Criticizing & $\square$ & $\square$ & $\square$ & $\square$ & $\square$ \\
\hline Cruel & $\square$ & $\square$ & $\square$ & $\square$ & $\square$ \\
\hline Damning & $\square$ & $\square$ & $\square$ & $\square$ & $\square$ \\
\hline Demanding & $\square$ & $\square$ & $\square$ & $\square$ & $\square$ \\
\hline Distant & $\square$ & $\square$ & $\square$ & $\square$ & $\square$ \\
\hline Dominating & $\square$ & $\square$ & $\square$ & $\square$ & $\square$ \\
\hline Firm & $\square$ & $\square$ & $\square$ & $\square$ & $\square$ \\
\hline Giving & $\square$ & $\square$ & $\square$ & $\square$ & $\square$ \\
\hline Guiding & $\square$ & $\square$ & $\square$ & $\square$ & $\square$ \\
\hline
\end{tabular}




\begin{tabular}{|c|c|c|c|c|c|}
\hline & $\begin{array}{l}\text { God is } \\
\text { NEVER like } \\
\text { this. }\end{array}$ & $\begin{array}{c}\text { God is } \\
\frac{\text { RARELYlike }}{\text { this }}\end{array}$ & $\begin{array}{c}\text { God is } \\
\text { SOMETIMES } \\
\text { like this }\end{array}$ & $\begin{array}{c}\text { God is } \\
\text { OFTEN like } \\
\text { this }\end{array}$ & $\begin{array}{c}\text { God is } \\
\frac{\text { ALWAYS like }}{\text { this }}\end{array}$ \\
\hline Harsh & $\square$ & & $\square$ & $\square$ & ᄂ \\
\hline Inaccessible & $\square$ & $\square$ & $\square$ & $\square$ & $\square$ \\
\hline Jealous & $\square$ & $\square$ & $\square$ & $\square$ & $\square$ \\
\hline Judging & $\square$ & $\square$ & $\square$ & $\square$ & $\square$ \\
\hline Kind & $\square$ & $\square$ & $\square$ & $\square$ & $\checkmark$ \\
\hline Loving & E & & $\square$ & $\square$ & L \\
\hline Nearby & $\square$ & $\square$ & $\square$ & $\square$ & $\square$ \\
\hline Nurturing & $\square$ & $\square$ & $\square$ & $\square$ & $\square$ \\
\hline Passive & $\square$ & $\square$ & $\square$ & $\square$ & $\square$ \\
\hline Patient & $\square$ & & $\square$ & $\square$ & $\square$ \\
\hline Peaceful & $\square$ & $\square$ & $\square$ & $\square$ & $\square$ \\
\hline Punishing & $\square$ & $\square$ & $\square$ & $\square$ & $\square$ \\
\hline Quiet & $\square$ & $\square$ & $\square$ & $\square$ & $\square$ \\
\hline Remote & $\square$ & $\square$ & $\square$ & $\square$ & $\square$ \\
\hline Responsive & $\square$ & $\square$ & $\square$ & $\square$ & $\square$ \\
\hline Rigid & E & 7 & $\square$ & $\square$ & $\square$ \\
\hline Sovereign & $\square$ & $\square$ & $\square$ & $\square$ & $\square$ \\
\hline Spiteful & $\square$ & $\square$ & $\square$ & $\square$ & $\bar{\square}$ \\
\hline Stern & $\square$ & $\square$ & $\square$ & $\square$ & $\square$ \\
\hline Still & $\square$ & $\square$ & $\square$ & $\square$ & $\square$ \\
\hline Strict & & & $\square$ & $\square$ & $\square$ \\
\hline Strong & 7 & & $\square$ & $\square$ & $\square$ \\
\hline Supportive & $\square$ & $\square$ & $\square$ & $\square$ & $\square$ \\
\hline Timely & & 7 & $\square$ & $\square$ & $\square$ \\
\hline Tough & $\square$ & $\square$ & $\square$ & $\square$ & $\square$ \\
\hline Unapproachable & 7 & & $\square$ & $\square$ & $\square$ \\
\hline Unbiased & $\square$ & $\square$ & $\square$ & $\square$ & $\square$ \\
\hline Understanding & $\square$ & $\square$ & $\square$ & $\square$ & $\square$ \\
\hline Universal & $\square$ & $\square$ & $\square$ & $\square$ & $\square$ \\
\hline Unyielding & $\square$ & $\square$ & $\square$ & $\square$ & $\square$ \\
\hline Weak & $\square$ & $\square$ & $\square$ & $\square$ & $\square$ \\
\hline Wrathful & $\square$ & $\square$ & $\square$ & $\square$ & $\square$ \\
\hline
\end{tabular}




\section{Appendix B: Background Questionnaire}

The following information is collected to help us determine whether descriptions vary as a function of demographic and backgrounds. Please answer all of the following questions as they describe you.

A. Gender (circle ONE):

1. Female

2. Male

B. Age: yrs

C. Which of the following religious groups did you affiliate with as a child? (Circle as many as applies):

1. Baha'i

2. Buddhist

Theravada, Mahayana, Vajrayana, or other

3. Christian/Catholic

4. Christian/Non-Catholic

Which denomination?

5. Jewish

Orthodox, Reform, or other

6. Muslim

Sunnis, Shi'ites, or other

7. Spiritual, New Age, Pagan

8. Other

9. None 
D. With which of the following religious groups do you currently affiliate? (circle as many as applies):

1. Baha'i

2. Buddhist

Theravada, Mahayana, Vajrayana, or other

3. Christian/Catholic

4. Christian/Non-Catholic

Which denomination?

5. Jewish

Orthodox, Reform, or other

6. Muslim

Sunnis, Shi'ites, or other

7. Spiritual, New Age, Pagan

8. Other

9. None

E. To what extent do you consider your religious or spiritual views to be liberal or conservative?

\begin{tabular}{|l|l|l|l|l|}
\hline Very Liberal & $\begin{array}{l}\text { Somewhat } \\
\text { Liberal }\end{array}$ & $\begin{array}{l}\text { Somewhat } \\
\text { Conservative }\end{array}$ & $\begin{array}{l}\text { Very } \\
\text { Conservative }\end{array}$ & Don't know \\
\hline 1 & 2 & 3 & 4 & 5 \\
\hline
\end{tabular}

F. To what extent do you think the religious group with which you currently affiliate to be liberal or conservative?

\begin{tabular}{|l|l|l|l|l|}
\hline Very Liberal & $\begin{array}{l}\text { Somewhat } \\
\text { Liberal }\end{array}$ & $\begin{array}{l}\text { Somewhat } \\
\text { Conservative }\end{array}$ & $\begin{array}{l}\text { Very } \\
\text { Conservative }\end{array}$ & Don't know \\
\hline 1 & 2 & 3 & 4 & 5 \\
\hline
\end{tabular}




\section{Appendix C: World Assumptions Scale \\ (Janoff-Bulman, 1989.)}

Below are thirty two (32) statements with which you may agree or disagree. Using the 16 scale below, indicate your agreement with each item by placing the appropriate number on the line preceding that item. Please be open and honest in your responding.

\begin{tabular}{|c|c|c|c|c|c|}
\hline 1 & 2 & 3 & 4 & 5 & 6 \\
\hline $\begin{array}{c}\text { Disagree } \\
\text { completely }\end{array}$ & Disagree & $\begin{array}{c}\text { Somewhat } \\
\text { Disagree }\end{array}$ & $\begin{array}{c}\text { Somewhat } \\
\text { Agree }\end{array}$ & Agree & $\begin{array}{c}\text { Agree } \\
\text { Completely }\end{array}$ \\
\hline
\end{tabular}

\begin{tabular}{|c|c|c|c|c|c|c|c|}
\hline & \multirow[t]{2}{*}{$\begin{array}{c}\text { Disagree } \\
\text { Completely }\end{array}$} & \multirow[t]{2}{*}{ Disagree } & \multirow[t]{2}{*}{$\begin{array}{l}\text { Somewhat } \\
\text { Disagree }\end{array}$} & \multirow[t]{2}{*}{$\begin{array}{l}\text { Somewhat } \\
\text { Agree }\end{array}$} & \multirow[t]{2}{*}{ Agree } & \multirow[t]{2}{*}{$\begin{array}{c}\text { Agree } \\
\text { Completely }\end{array}$} \\
\hline 1 & $\begin{array}{l}\text { Misfortune is least likely } \\
\text { to strike worthy, decent } \\
\text { people. }\end{array}$ & & & & & & \\
\hline 2 & $\begin{array}{l}\text { People are naturally } \\
\text { unfriendly and unkind. }\end{array}$ & & & & & & \\
\hline 3 & $\begin{array}{l}\text { Bad events are } \\
\text { distributed to people at } \\
\text { random. }\end{array}$ & & & & & & \\
\hline 4 & $\begin{array}{l}\text { Human nature is } \\
\text { basically good. }\end{array}$ & & & & & & \\
\hline 5 & $\begin{array}{l}\text { The good things } \\
\text { happen in this world far } \\
\text { outnumber the bad. }\end{array}$ & & & & & & \\
\hline 6 & $\begin{array}{l}\text { The course of our lives } \\
\text { is largely determined } \\
\text { by chance. }\end{array}$ & & & & & & \\
\hline 7 & $\begin{array}{l}\text { Generally, people } \\
\text { deserve what they get } \\
\text { in this world. }\end{array}$ & & & & & & \\
\hline 8 & $\begin{array}{l}\text { I often think I am no } \\
\text { good at all. }\end{array}$ & & & & & & \\
\hline 9 & $\begin{array}{l}\text { There is more good } \\
\text { than evil in the world. }\end{array}$ & & & & & & \\
\hline 10 & $\begin{array}{l}\text { I am basically a lucky } \\
\text { person. }\end{array}$ & & & & & & \\
\hline
\end{tabular}




\begin{tabular}{|c|c|c|c|c|c|c|c|}
\hline & & $\begin{array}{c}\text { Disagree } \\
\text { Completely }\end{array}$ & Disagree & $\begin{array}{l}\text { Somewhat } \\
\text { Disagree }\end{array}$ & $\begin{array}{c}\text { Somewhat } \\
\text { Agree }\end{array}$ & Agree & $\begin{array}{c}\text { Agree } \\
\text { Completely }\end{array}$ \\
\hline 11 & $\begin{array}{l}\text { Peoples' misfortune } \\
\text { results from mistakes } \\
\text { they have made. }\end{array}$ & & & & & & \\
\hline 12 & $\begin{array}{l}\text { People don't really care } \\
\text { what happens to the } \\
\text { next person. }\end{array}$ & & & & & & \\
\hline 13 & $\begin{array}{l}\text { I usually behave in } \\
\text { ways that are likely to } \\
\text { maximize good results } \\
\text { for me. }\end{array}$ & & & & & & \\
\hline 14 & $\begin{array}{l}\text { People will experience } \\
\text { good fortune if they } \\
\text { themselves are good. }\end{array}$ & & & & & & \\
\hline 15 & $\begin{array}{l}\text { Life is too full on } \\
\text { uncertainties that are } \\
\text { determined by chance. }\end{array}$ & & & & & & \\
\hline 16 & $\begin{array}{l}\text { When I think about it, I } \\
\text { consider myself very } \\
\text { lucky. }\end{array}$ & & & & & & \\
\hline 17 & $\begin{array}{l}\text { I almost always make } \\
\text { an effort to prevent } \\
\text { bad things from } \\
\text { happening to me. }\end{array}$ & & & & & & \\
\hline 18 & $\begin{array}{l}\text { I have a low opinion of } \\
\text { myself. }\end{array}$ & & & & & & \\
\hline 19 & $\begin{array}{l}\text { By and large, good } \\
\text { people get what they } \\
\text { deserve in this world. }\end{array}$ & & & & & & \\
\hline 20 & $\begin{array}{l}\text { Through our actions we } \\
\text { can prevent bad things } \\
\text { from happening to us. }\end{array}$ & & & & & & \\
\hline 21 & $\begin{array}{l}\text { Looking at y life, I } \\
\text { realize that chance } \\
\text { events have worked } \\
\text { out well for me. }\end{array}$ & & & & & & \\
\hline 22 & $\begin{array}{l}\text { If people took } \\
\text { preventive actions, } \\
\text { most misfortune could } \\
\text { be avoided. }\end{array}$ & & & & & & \\
\hline
\end{tabular}




\begin{tabular}{|c|c|c|c|c|c|c|c|}
\hline & \multirow[t]{2}{*}{$\begin{array}{c}\text { Disagree } \\
\text { Completely }\end{array}$} & \multirow[t]{2}{*}{ Disagree } & \multirow[t]{2}{*}{$\begin{array}{l}\text { Somewhat } \\
\text { Disagree }\end{array}$} & \multirow[t]{2}{*}{$\begin{array}{c}\text { Somewhat } \\
\text { Agree }\end{array}$} & \multirow[t]{2}{*}{ Agree } & \multirow[t]{2}{*}{$\begin{array}{c}\text { Agree } \\
\text { Completely }\end{array}$} \\
\hline 23 & $\begin{array}{l}\text { I take the actions } \\
\text { necessary to protect } \\
\text { myself against } \\
\text { misfortune. }\end{array}$ & & & & & & \\
\hline 24 & $\begin{array}{l}\text { In general, life is } \\
\text { mostly a gamble. }\end{array}$ & & & & & & \\
\hline 25 & $\begin{array}{l}\text { The world is a good } \\
\text { place. }\end{array}$ & & & & & & \\
\hline 26 & $\begin{array}{l}\text { People are basically } \\
\text { kind and helpful. }\end{array}$ & & & & & & \\
\hline 27 & $\begin{array}{l}\text { I usually behave so as } \\
\text { to bring about the } \\
\text { greatest good for me. }\end{array}$ & & & & & & \\
\hline 28 & $\begin{array}{l}\text { I am very satisfied with } \\
\text { the kind of person I } \\
\text { am. }\end{array}$ & & & & & & \\
\hline 29 & $\begin{array}{l}\text { When bad things } \\
\text { happen, it is typically } \\
\text { because people have } \\
\text { not taken the } \\
\text { necessary actions to } \\
\text { protect themselves. }\end{array}$ & & & & & & \\
\hline 30 & $\begin{array}{l}\text { If you look closely } \\
\text { enough, you will see } \\
\text { that the world is full of } \\
\text { goodness. }\end{array}$ & & & & & & \\
\hline 31 & $\begin{array}{l}\text { I have reason to be } \\
\text { ashamed of my } \\
\text { personal character. }\end{array}$ & & & & & & \\
\hline 32 & $\begin{array}{l}\text { I am luckier than most } \\
\text { people. }\end{array}$ & & & & & & \\
\hline
\end{tabular}




\section{Appendix D: Multidimensional Locus of Control Scales: God Control Revision}

(Welton, Adkins, Ingle, \& Dixon, 1996)

Below are 32 statements with which you may agree or disagree. Using the 1-6 scale below, indicate your agreement with each item by placing the appropriate number on the line preceding that item. Please be open and honest in your responding.

\begin{tabular}{|c|c|c|c|c|c|}
\hline 1 & 2 & 3 & 4 & 5 & 6 \\
\hline $\begin{array}{c}\text { Strongly } \\
\text { disagree }\end{array}$ & Disagree & $\begin{array}{c}\text { Somewhat } \\
\text { disagree }\end{array}$ & $\begin{array}{c}\text { Somewhat } \\
\text { agree }\end{array}$ & Agree & $\begin{array}{c}\text { Strongly } \\
\text { agree }\end{array}$ \\
\hline
\end{tabular}

\begin{tabular}{|l|l|l|l|l|l|l|}
\cline { 2 - 6 } \multicolumn{1}{l|}{} & $\begin{array}{l}\text { Strongly } \\
\text { Disagree }\end{array}$ & Disagree & $\begin{array}{c}\text { Slightly } \\
\text { Disagree }\end{array}$ & $\begin{array}{c}\text { Slightly } \\
\text { Agree }\end{array}$ & Agree & $\begin{array}{c}\text { Strongly } \\
\text { Agree }\end{array}$ \\
\hline $\begin{array}{l}\text { 1. Whether or not I get to be a } \\
\text { leader depends mostly on my } \\
\text { ability. }\end{array}$ & & & & & & \\
\hline $\begin{array}{l}\text { 2. To a great extent my life is } \\
\text { controlled by accidental } \\
\text { happenings. }\end{array}$ & & & & & & \\
\hline $\begin{array}{l}\text { 3. What happens in my life is } \\
\text { determined by God's purpose. }\end{array}$ & & & & & & \\
\hline $\begin{array}{l}\text { 4. I feel like what happens in } \\
\text { my life is mostly determined by } \\
\text { powerful people. }\end{array}$ & & & & & & \\
\hline $\begin{array}{l}\text { 5. Whether or not I get into a } \\
\text { car accident depends mostly on } \\
\text { how good a driver I } \\
\text { Am. }\end{array}$ & & & & & & \\
\hline $\begin{array}{l}\text { 6. When I make plans, I am } \\
\text { almost certain to make them } \\
\text { work. }\end{array}$ & & & & & & \\
\hline $\begin{array}{l}\text { 7. My life is primarily } \\
\text { controlled by God. }\end{array}$ & & & & & & \\
\hline $\begin{array}{l}\text { 8. Often there is no chance of } \\
\text { protecting my personal interests } \\
\text { from bad luck happenings. }\end{array}$ & & & & & & \\
\hline $\begin{array}{l}\text { 9. When I get what I want, it's } \\
\text { usually because I'm lucky. }\end{array}$ & & & & & & \\
\hline
\end{tabular}




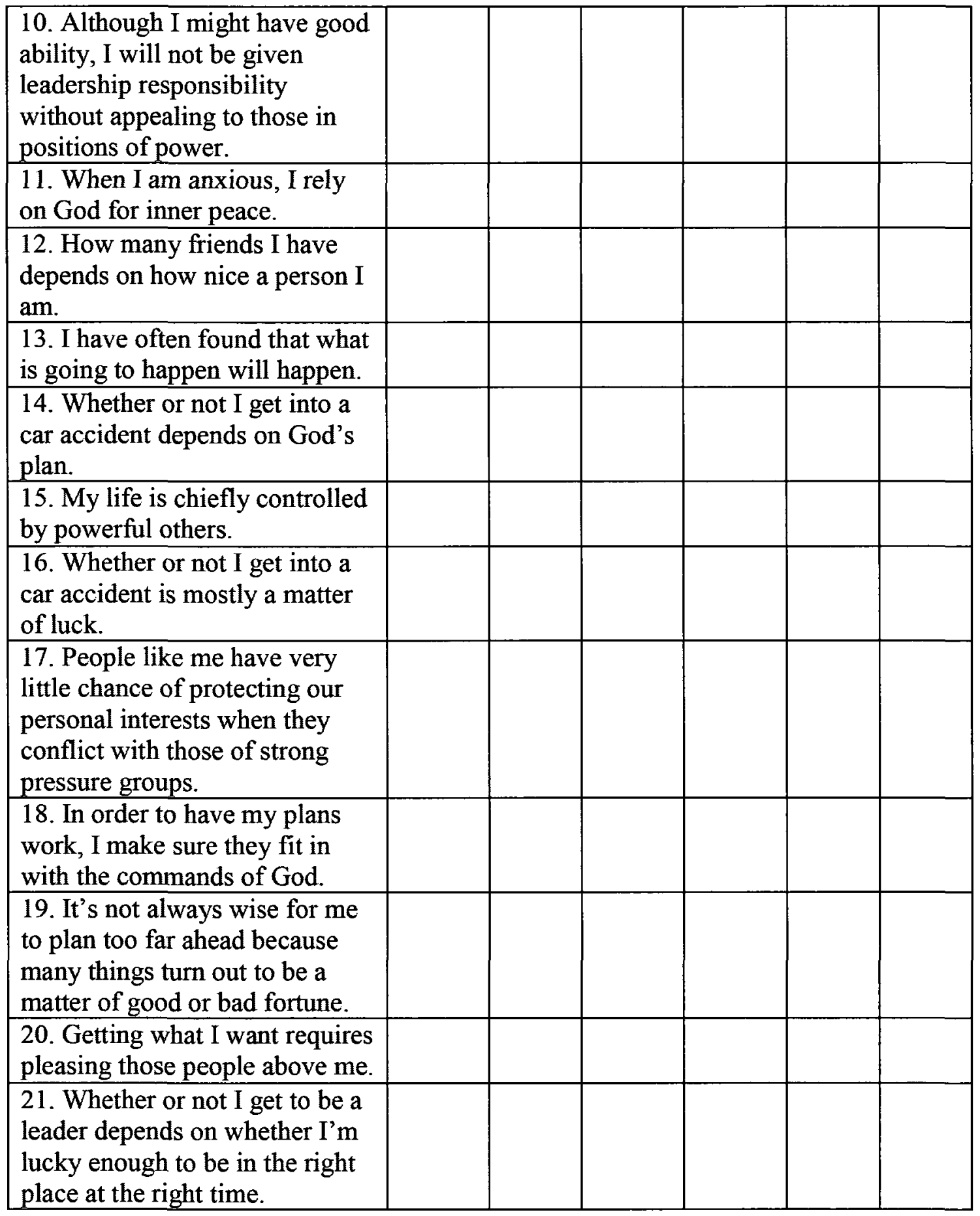




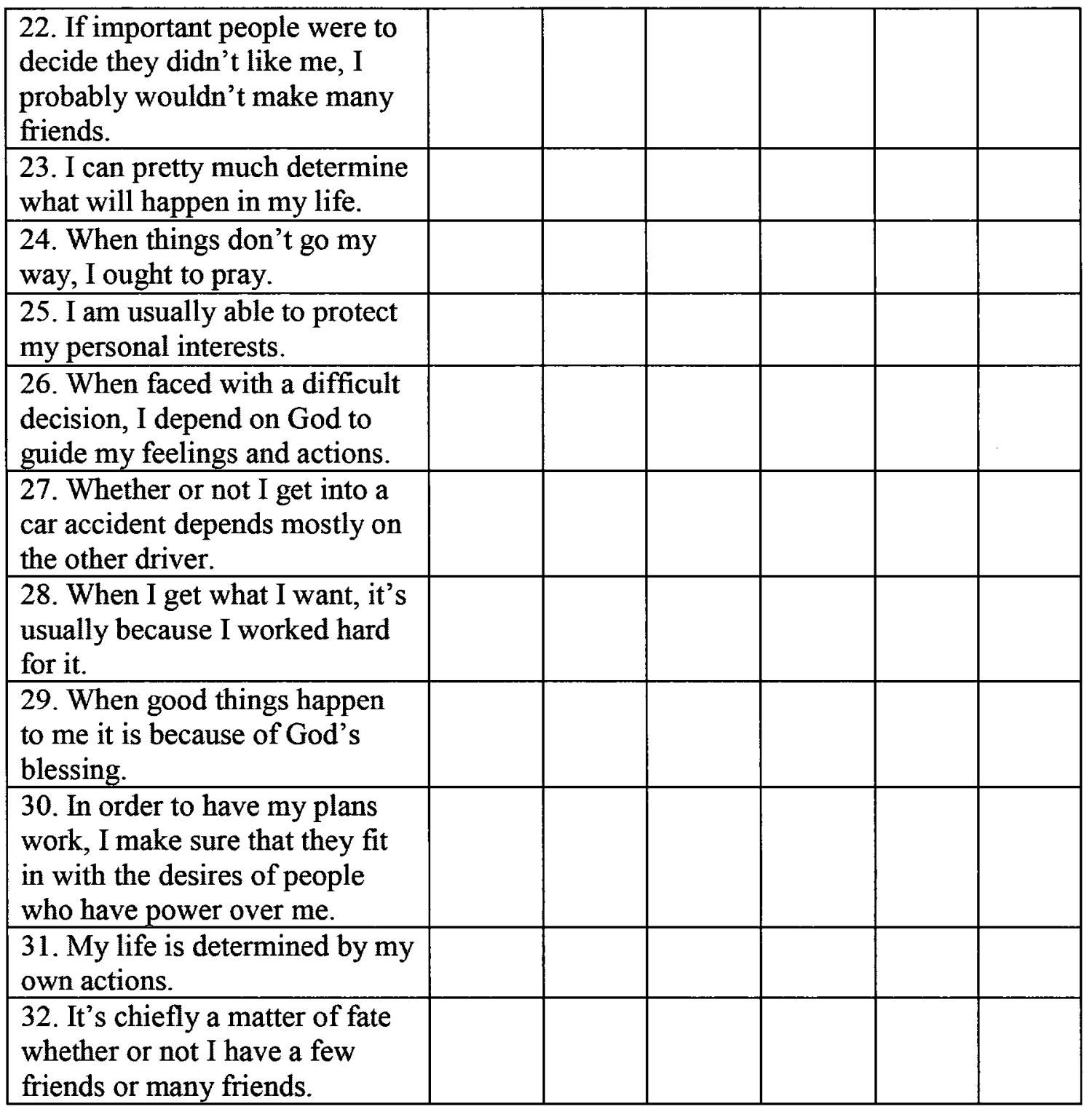




\section{Appendix E: Religious Problem-solving Scale}

(Pargament, Kennell, Hathaway, Grevengoed, Newman, \& Jones, 1988)

When things are difficult or stressful, people cope in different days. For each of the following statements, please indicate how often, if ever, you cope in the way indicated.

$\begin{array}{ccccc}1 & 2 & 3 & 4 & 5 \\ \text { Never } & \begin{array}{c}\text { Hardly } \\ \text { ever }\end{array} & \begin{array}{c}\text { Neutral or } \\ \text { no opinion }\end{array} & \text { Often } & \text { Always } \\ & & & \end{array}$

\begin{tabular}{|c|c|c|c|c|c|c|}
\hline & & Never & $\begin{array}{c}\text { Hardly } \\
\text { Ever }\end{array}$ & Neutral & Often & Always \\
\hline 1 & $\begin{array}{l}\text { When I have a problem, I talk to } \\
\text { God about it and together we decide } \\
\text { what it means. }\end{array}$ & & & & & \\
\hline 2 & $\begin{array}{l}\text { Rather than trying to come up with } \\
\text { the right solution to a problem } \\
\text { myself, I let God decide how to deal } \\
\text { with it. }\end{array}$ & & & & & \\
\hline 3 & $\begin{array}{l}\text { When faced with trouble, I deal with } \\
\text { my feelings without God's help. }\end{array}$ & & & & & \\
\hline 4 & $\begin{array}{l}\text { When a situation makes me anxious, } \\
\text { I wait for God to take those feelings } \\
\text { away. }\end{array}$ & & & & & \\
\hline 5 & $\begin{array}{l}\text { Together, God and I put my plans } \\
\text { into action. }\end{array}$ & & & & & \\
\hline 6 & $\begin{array}{l}\text { When it comes to deciding how to } \\
\text { solve a problem, God and I work } \\
\text { together as partners. }\end{array}$ & & & & & \\
\hline 7 & $\begin{array}{l}\text { I act to solve my problems without } \\
\text { God's help. }\end{array}$ & & & & & \\
\hline 8 & $\begin{array}{l}\text { When I have difficulty, I decide } \\
\text { what it means by myself without } \\
\text { God's help. }\end{array}$ & & & & & \\
\hline 9 & $\begin{array}{l}\text { I don't spend much time thinking } \\
\text { about troubles I've had; God makes } \\
\text { sense of them for me. }\end{array}$ & & & & & \\
\hline 10 & $\begin{array}{l}\text { When considering a difficult } \\
\text { situation, God and I work together to } \\
\text { think of possible solutions. }\end{array}$ & & & & & \\
\hline
\end{tabular}




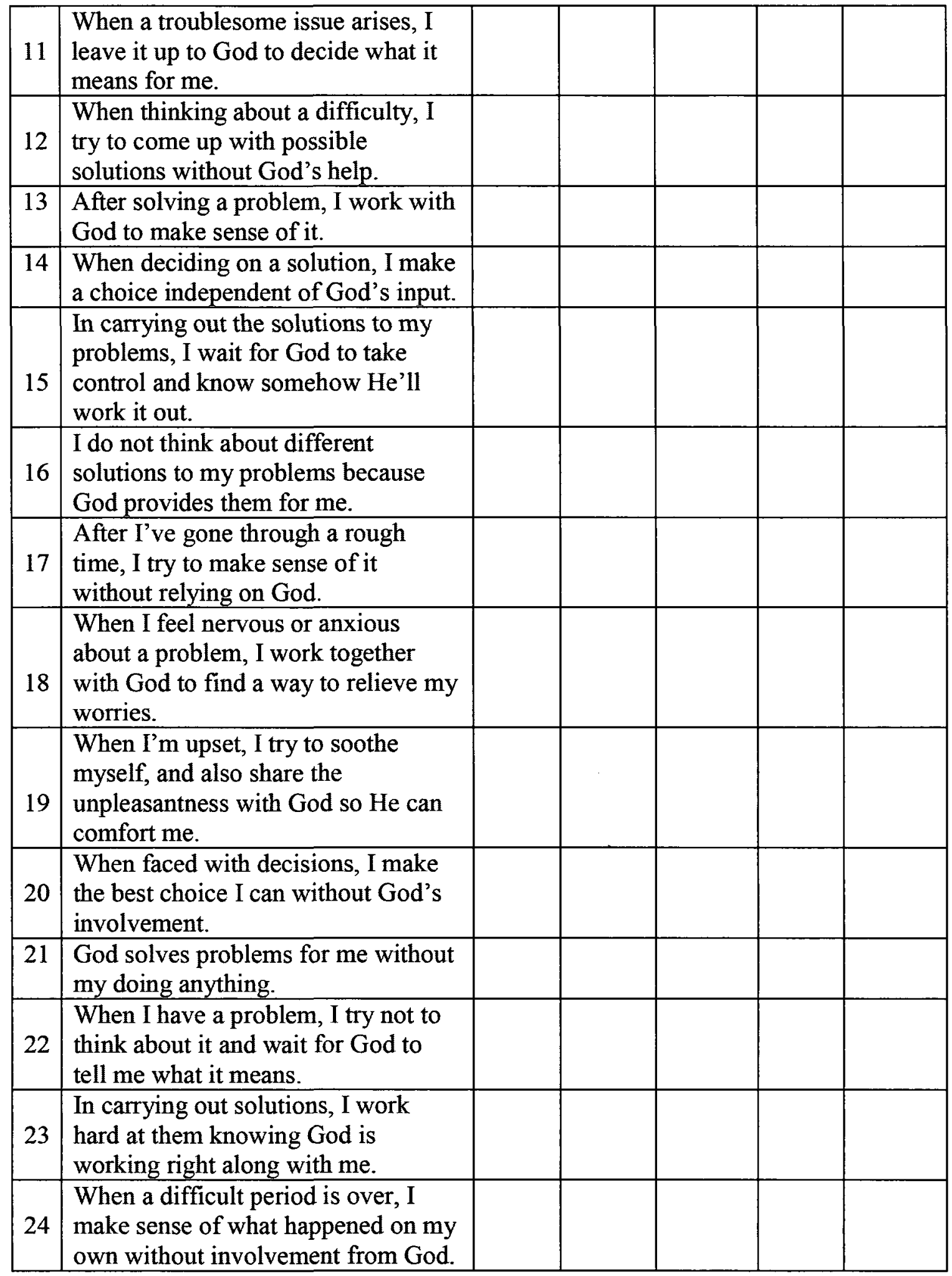




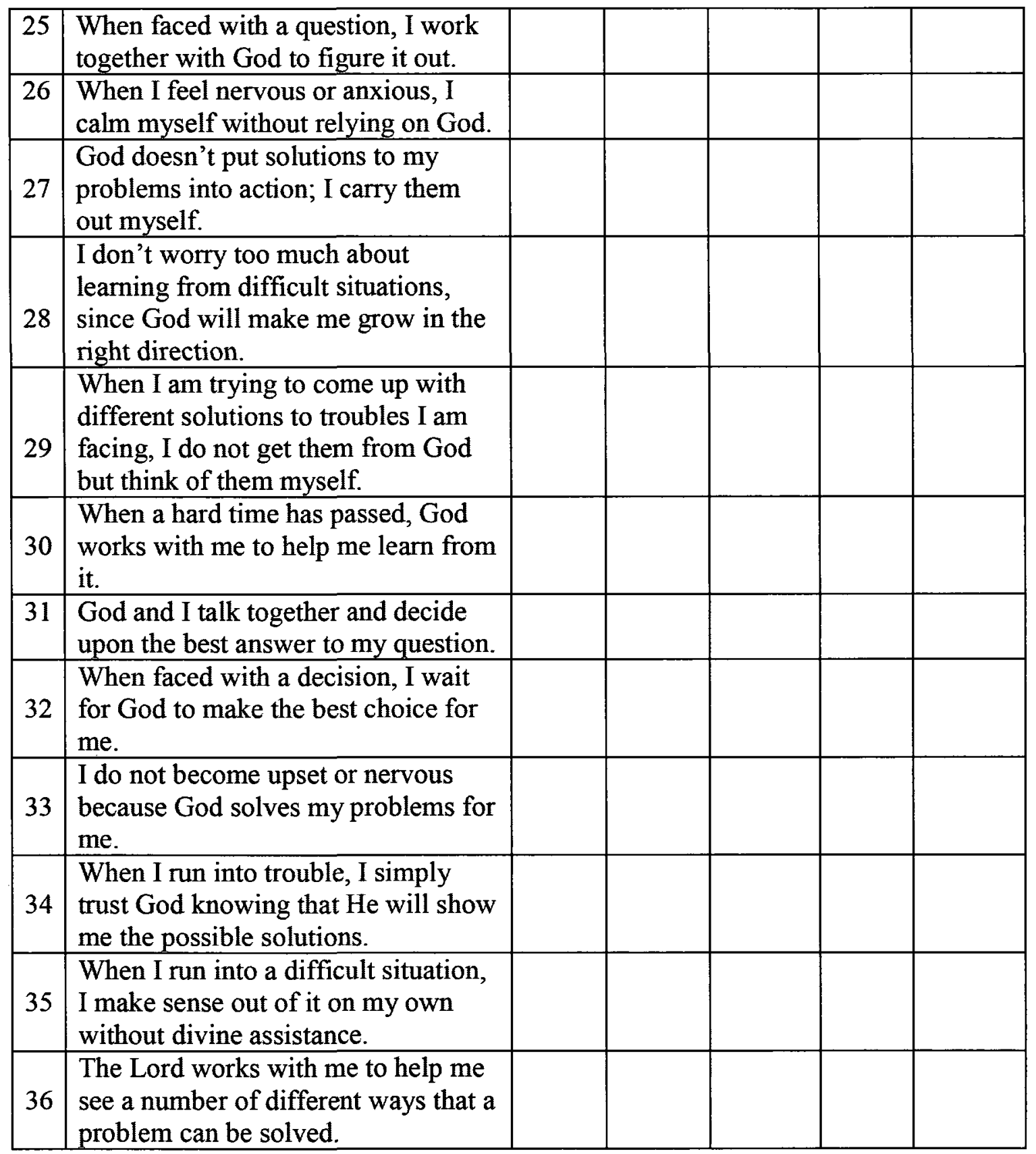




\section{Appendix F: Liberalism \& Conservatism Scale (Revised)}

(Stellway, 1973)

Please indicate the extent to which you agree with each of the following statements:

2

1

Strongly disagree
3

Disagree
Neutral or no opinion
4

Somewhat Agree
5

6

Agree

Strongly

Agree

\begin{tabular}{|c|c|c|c|c|c|c|}
\hline & $\begin{array}{l}\text { Strongly } \\
\text { disagree }\end{array}$ & Disagree & $\begin{array}{l}\text { Neutral or } \\
\text { no opinion }\end{array}$ & Agree & $\begin{array}{l}\text { Strongly } \\
\text { Agree }\end{array}$ \\
\hline \begin{tabular}{|l|}
1 \\
\end{tabular} & $\begin{array}{l}\text { Science and religion are both } \\
\text { equally good ways to find truth. }\end{array}$ & & & & & \\
\hline \begin{tabular}{|l|}
2 \\
\end{tabular} & $\begin{array}{l}\text { Miracles did not happen as the } \\
\text { [Bible, Qur,ân, Torah, etc.] } \\
\text { says they did but have been } \\
\text { used as examples. }\end{array}$ & & & & & \\
\hline 3 & $\begin{array}{l}\text { "God" and "Nature" are in } \\
\text { some ways the same thing. }\end{array}$ & & & & & \\
\hline 4 & $\begin{array}{l}\text { If a person does good for others, } \\
\text { he or she will enjoy fellowship } \\
\text { with God/Allâh/Higher Power. }\end{array}$ & & & & & \\
\hline 5 & $\begin{array}{l}\text { A person must seek God's } \\
\text { forgiveness to enjoy fellowship } \\
\text { with God. }\end{array}$ & & & & & \\
\hline 6 & $\begin{array}{l}\text { If they stay true to God, people } \\
\text { who suffer in this life are sure } \\
\text { to be rewarded in the next. }\end{array}$ & & & & & \\
\hline 7 & $\begin{array}{l}\text { Religious/spirituality truth is } \\
\text { higher than any form of truth. }\end{array}$ & & & & & \\
\hline 8 & $\begin{array}{l}\text { The [Bible, Qur } \square \text { ân, Torah, } \\
\text { etc.] is God's message to } \\
\text { people and all that it says is } \\
\text { true. }\end{array}$ & & & & & \\
\hline
\end{tabular}




\section{Appendix G: Religious Identity}

Please indicate the extent to which you agree with each of the following statements:

1. My Christian identity is very important to me.

$\begin{array}{cccccccc}\begin{array}{c}\text { Definitely } \\ \text { disagree }\end{array} & \begin{array}{c}\text { Mostly } \\ \text { disagree }\end{array} & \begin{array}{c}\text { Somewhat } \\ \text { disagree }\end{array} & \begin{array}{c}\text { Slightly } \\ \text { disagree }\end{array} & \begin{array}{c}\text { Slightly } \\ \text { agree }\end{array} & \begin{array}{c}\text { Somewhat } \\ \text { agree }\end{array} & \begin{array}{c}\text { Mostly } \\ \text { agree }\end{array} & \begin{array}{c}\text { Definitely } \\ \text { agree }\end{array} \\ 1 & 2 & 3 & 4 & 5 & 6 & 7 & 8 \\ \square & \square & \square & \square & \square & \square & \square & \square\end{array}$

2. Being a Christian is a reflection of who I am.

$\begin{array}{cccccccc}\begin{array}{c}\text { Definitely } \\ \text { disagree }\end{array} & \begin{array}{c}\text { Mostly } \\ \text { disagree }\end{array} & \begin{array}{c}\text { Somewhat } \\ \text { disagree }\end{array} & \begin{array}{c}\text { Slightly } \\ \text { disagree }\end{array} & \begin{array}{c}\text { Slightly } \\ \text { agree }\end{array} & \begin{array}{c}\text { Somewhat } \\ \text { agree }\end{array} & \begin{array}{c}\text { Mostly } \\ \text { agree }\end{array} & \begin{array}{c}\text { Definitely } \\ \text { agree }\end{array} \\ 1 & 2 & 3 & 4 & 5 & 6 & 7 & 8 \\ \square & \square & \square & \square & \square & \square & \square & \square\end{array}$

3. I feel strong ties to other Christians.

$\begin{array}{cccccccc}\begin{array}{c}\text { Definitely } \\ \text { disagree }\end{array} & \begin{array}{c}\text { Mostly } \\ \text { disagree }\end{array} & \begin{array}{c}\text { Somewhat } \\ \text { disagree }\end{array} & \begin{array}{c}\text { Slightly } \\ \text { disagree }\end{array} & \begin{array}{c}\text { Slightly } \\ \text { agree }\end{array} & \begin{array}{c}\text { Somewhat } \\ \text { agree }\end{array} & \begin{array}{c}\text { Mostly } \\ \text { agree }\end{array} & \begin{array}{c}\text { Definitely } \\ \text { agree }\end{array} \\ 1 & 2 & 3 & 4 & 5 & 6 & 7 & 8 \\ \square & \square & \square & \square & \square & \square & \square & \square\end{array}$




\section{Appendix H: Debriefing}

Thank you for your participation in this study. All the information we collected will be completely confidential, and there will be no way of identifying your responses in the data archive. Your participation today is greatly appreciated and will help us better understand the similarities and differences in how people of different faiths understand the Sacred. Some people will see the Divine as loving whereas others may see him (or Her) as more judging, or distant. We want to know the extent to which people of Jewish faith, Muslim faith, Christian faith, Hindu faith, and other faiths have a common or distinct view of the Divine. We are also interested in examining differences in perception of the Divine within religious groups. That is, not all Muslims will have the same view of the Divine, just as not all Christians will have the same view of the Divine. We are also interested in understanding factors that correlate with different views of the Divine. For example, is the view that you have about the Divine related to your level of self-esteem, or beliefs that you might have about personal control, the benevolence of the world, or the extent to which your beliefs are liberal or conservative. This study is designed to answer these questions.

Why is this important to scientists or the general public?

This is important because religion has been the root of many misunderstandings, and in our ever growing multicultural society, it would encourage tolerance and understanding of others different than ourselves. We often focus on the difference between "us" and "them", but perhaps we have more in common than not.

Where can I learn more? What if I have questions later? If you would like to read more about the topic of individual's Divine concept, or receive a brief review of major findings of this research, contact Shelley C Taylor by email at shelley.taylor@cogeco.ca. Please contact Shelley Taylor or Dr. Chris Davis (613-5202600, ext. 2251; chris_davis@carleton.ca) if you have any questions about this research.

If you have ethical concerns regarding this research, please contact Dr. Avi Parush, Chair, Carleton University Ethics Committee for Psychological Research, (613-5202600, ext. 6026) or Dr. Janet Mantler (Chair, Dept. of Psychology, 613-520-2600, ext. 4173). 
Appendix I: The 99 Attributes of Allâh

(Samat, 2003).

Name

ALLÂH

AR-RAHMAN

AR-RAHIIM

AL-MALIK

AL-QUDDUS

AS-SALAAM

AL-MU'MIN

AL-MUHAYMIN

AL-'AZIIZ

AL-JABBAAR

AL-

MUTAKABBIR

AL-KHAALIQ

AL-BAARI'

AL-MUSAWWIR

AL-GAFFAAR

AL-QAHHAAR

AL-WAHHAAB

AR-RAZZAAQ

AL-FATTAAH

AL-'ALIIM

AL-QAABIDH

AL-BAASIT

AL-KHAAFIDH

AR-RAAFIK

AL-MU'IZZ

AL-MUDZILL
Translation

The Compassionate

The Merciful

The King

The Holy

The Saviour

The Bestower of security

The Protector

The Mighty

The Compeller

The Majestic

The Creator

The Planner

The Fashioner

The Forgiver

The Subduer

The Bestower

The Provider

The Opener, The Judge

The All-Knowing

The Withholder

The Enlarger

The Abaser

The Exalter

The Honourer

The Humiliator
Some relevant verses from the Qur'an

$(1: 1)(3: 18)(5: 109)(6: 124)(7: 180)(8: 40)$

$(1: 3)(17: 110)(19: 58)(21: 112)(27: 30)$

$(2: 163)(3: 31)(4: 100)(5: 3)(5: 98)$

$(20: 114)(23: 116)(59: 23)(62: 1)(114: 2)$

$(59: 23)(62: 1)$

$(59: 23)$

$(59: 23)$

$(59: 23)$

$(3: 6)(4: 158)(9: 40)(9: 71)(48: 7)$

$(59: 23)$

$(59: 23)$

$(6: 102)(13: 16)(39: 62)(40: 62)(59: 24)$

$(59: 24)$

$(59: 24)$

$(20: 82)(38: 66)(39: 5)(40: 42)(71: 10)$

$(13: 16)(14: 48)(38: 65)(39: 4)(40: 16)$

$(3: 8)(38: 9)(38: 35)$

$(51: 58)$

$(34: 26)$

$(2: 158)(3: 92)(4: 35)(24: 41)(33: 40)$

$(2: 245)$

(2:245)

(3:26)

(3:26) 
AS-SAMIIK'

AL-BASIIR

AL-HAKAM

AL-'ADL

AL-LATIIF

AL-KHABIIR

AL-HALIIM

AL-'AZIIM

AL-GAFUUR

AS-SHAKUUR

AL-'ALII

AL-KABIIR

AL-HAFIIZ

AL-MUGHIIT

AL-HASIIB

AL-JALIIL

AL-KARIIM

AR-RAQIIB

AL-MUJIIB

AL-WAASIK

AL-HAKIIM

AL-WADUUD

AL-MAJIID

AL-BAA'ITH

ASH-SHAHIID

AL-HAQQ

AL-WAKIIL

AL-QAWII

AL-MATIIN

AL-WALI
The All-Hearing

The All-Seeing

The Judge

The Just, The Equitable

The Subtle

The Aware

The Forbearing

The Tremendous

The All-Forgiving

The Grateful

The High

The Great

The Guardian

The Sustainer

The Reckoner

The Majestic

The Generous

The Watchful

The Responsive

The All-Embracing

The Wise

The Loving

The Venerable

The Resurrector of the Dead

The Witness

The Truth

The Trustee

The Strong

The Firm

The Protector
$(2: 127)(2: 137)(2: 256)(8: 17)(49: 1)$

$(4: 58)(17: 1)(42: 11)(42: 27)(57: 4)$

$(22: 69)$

$(6: 103)(22: 63)(31: 16)(33: 34)(67: 14)$

$(6: 18)(17: 30)(49: 13)(59: 18)(63: 11)$

$(2: 225)(2: 235)(17: 44)(22: 59)(35: 41)$

$(2: 255)(42: 4)(56: 96)$

$(2: 173)(8: 69)(16: 110)(41: 32)(60: 7)$

$(35: 30)(35: 34)(42: 23)(64: 17)$

$(2: 255)(4: 34)(31: 30)(42: 4)(42: 51)$

$(13: 9)(22: 62)(31: 30)(34: 23)(40: 12)$

$(11: 57)(34: 21)(42: 6)$

$(4: 6)(4: 86)(33: 39)$

$(27: 40)(82: 6)$

$(4: 1)(5: 117)$

(11:61)

$(2: 115)(2: 261)(2: 268)(3: 73)(5: 54)$

$(2: 129)(2: 260)(31: 27)(46: 2)(57: 1)$

$(66: 2)$

$(11: 90)(85: 14)$

(11:73)

$(22: 7)$

$(4: 79)(4: 166)(22: 17)(41: 53)(48: 28)$

$(6: 62)(22: 6)(23: 116)(31: 30)$

$(3: 173)(4: 171)(28: 28)(33: 3)(73: 9)$

$(22: 40)(22: 74)(42: 19)(57: 25)(58: 21)$

$(51: 58)$

$(3: 68)(4: 45)(7: 196)(42: 28)(45: 19)$ 


\begin{tabular}{|c|c|c|}
\hline AL-HAMIID & The Praiseworthy & $(14: 1)(14: 8)(31: 12)(31: 26)(41: 42)$ \\
\hline AL-MUHSI & The Accountant & \\
\hline AL-MUBDIK & The Originator & $(10: 4)(10: 34)(27: 64)(29: 19)(85: 13)$ \\
\hline AL-MU'IID & The Restorer & $(10: 4)(10: 34)(27: 64)(29: 19)(85: 13)$ \\
\hline AL-MUHYII & The Giver of life & $(3: 156)(7: 158)(15: 23)(30: 50)(57: 2)$ \\
\hline AL-MUMIIT & The Giver of death & $(7: 158)(15: 23)(57: 2)$ \\
\hline AL-HAYY & The Ever-Living & $(2: 255)(3: 2)(20: 111)(25: 58)(40: 65)$ \\
\hline AL-QAYYUUM & The Self-Subsisting & $(2: 255)(3: 2)(20: 111)$ \\
\hline AL-WAAJID & The Inventor & \\
\hline AL-MAAJID & The Glorious & \\
\hline AL-WAAHID & The Unequaled & $(2: 163)(5: 73)(9: 31)(18: 110)(37: 4)$ \\
\hline AS-SAMAD & $\begin{array}{c}\text { The Eternal Supporter of } \\
\text { Creation }\end{array}$ & $(112: 2)$ \\
\hline AL-QAADIR & The Able & $(6: 65)(36: 81)(46: 33)(75: 40)(86: 8)$ \\
\hline AL-MUQTADIR & The Powerful & $(18: 45)(54: 42)(54: 55)$ \\
\hline AL-MUQADDIM & The Promoter & \\
\hline $\begin{array}{c}\text { AL- } \\
\text { MU'AKHKHIR }\end{array}$ & The Deferrer & $(71: 4)$ \\
\hline AL-AWWAL & The First & $(57: 3)$ \\
\hline AL-ÂKHIR & The Last & $(57: 3)$ \\
\hline AZ-ZAAHIR & The Manifest & $(57: 3)$ \\
\hline AL-BAATIN & The Hidden & $(57: 3)$ \\
\hline AL-WAALÎ & The Governor & \\
\hline AL-MUTA'AALî & The High Exalted & $(13: 9)$ \\
\hline AL-BARR & $\begin{array}{c}\text { The One Who Treats } \\
\text { Kindness }\end{array}$ & $(52: 28)$ \\
\hline AT-TAWWAAB & $\begin{array}{l}\text { The Accepter of } \\
\text { Repentance }\end{array}$ & $(2: 37)(2: 128)(4: 64)(49: 12)(110: 3)$ \\
\hline AL- MUNTAQIM & The Avenger & $(32: 22)(43: 41)(44: 16)$ \\
\hline AL-'AFUU & The Pardoner & $(4: 99)(4: 149)(22: 60)$ \\
\hline AR-RA'UUF & The Compassionate & $(3: 30)(9: 117)(57: 9)(59: 10)$ \\
\hline MAALIK-AL-MULK & Possessor of Sovereignty & $(3: 26)$ \\
\hline $\begin{array}{l}\text { DZUUL- JALAAL } \\
\text { WAL IKRAAM }\end{array}$ & $\begin{array}{c}\text { Lord of Majesty and } \\
\text { Bounty }\end{array}$ & $(55: 27)(55: 78)$ \\
\hline
\end{tabular}




$\begin{array}{lcl}\begin{array}{l}\text { AL-MUQSIT } \\ \text { AL-JAAMMIK }\end{array} & \begin{array}{c}\text { The Just, The Equitable } \\ \text { The Gatherer }\end{array} & \begin{array}{l}(3: 18) \\ (3: 9) \\ (2: 263)(3: 97)(39: 7)(47: 38)\end{array} \\ \text { AL-GHANII } & \text { The Self-Sufficient } & \begin{array}{l}(57: 24) \\ (9: 28)\end{array} \\ \text { AL-MUGHNII } & \text { The Enricher } & \\ \text { AL-MAANIK } & \text { The Preventer } \\ \text { AD-DHAAR } & \text { The Distresser } \\ \text { AN-NAAFIK } & \text { The Benefactor } \\ \text { AN-NUUR } & \text { The Light } \\ \text { AL-HAADI } & \text { The Guide } \\ \text { AL-BADIIK } & \text { The Originator } \\ \text { AL-BAAQII } & \text { The Eternal } \\ \text { AL-WAARIS } & \text { The Inheritor } \\ \text { AR-RASHIID } & \text { The Guide to the right } & (24: 117)(6: 35) \\ & \text { path } & \end{array}$

